\title{
RNA-based gene targeting therapies for human papillomavirus driven cancers
}

\author{
Ana María Salinas-Montalvo, Aroon Supramaniam, Nigel AJ McMillan*, Adi Idris*
}

Menzies Health Institute Queensland and School of Medical Sciences, Griffith University, Gold Coast, QLD, Australia

*Authors share senior authorship

\section{Corresponding author}

Dr Adi Idris

Menzies Health Institute Queensland and School of Pharmacy and Medical Sciences

Building G05, Room 3.37a

Gold Coast Campus

Griffith University, Queensland 4222, Australia

Phone: +61755527341

Email: a.idris@griffith.edu.au

Acknowledgements

None

\section{Funding}

None to disclose

Conflict of interest

None to disclose 


\title{
Highlights
}

- RNA-based therapies could be the "clinical key" for treating HPV cancers

- RNAi and CRISPR technology targeting HPV cancers could hold clinical promise

- miRNAs and lncRNAs could serve as future treatment modalities for HPV cancers

\begin{abstract}
While platinum-based chemotherapy, radiation therapy and or surgery are effective in reducing human papillomavirus (HPV) driven cancer tumours, they have some significant drawbacks, including low specificity for tumour, toxicity, and severe adverse effects. Though current therapies for HPV-driven cancers are effective, severe late toxicity associated with current treatments contributes to the deterioration of patient quality of life. This warrants the need for novel therapies for HPV derived cancers. In this short review, we examined RNA-based therapies targeting the major HPV oncogenes, including short-interfering RNAs (siRNAs) and clustered regularly interspaced short palindromic repeats (CRISPR) as putative treatment modalities. We also explore other potential RNA-based targeting approaches such as microRNAs (miRNAs), long non-coding RNAs (lncRNAs), and mRNA vaccines as future treatment modalities for HPV cancers. Some of these technologies have already been approved for clinical use for a range of other human diseases but not for HPV cancers. Here we explore the emerging evidence supporting the effectiveness of some of these gene-based therapies for HPV malignancies. In short, the evidence sheds promising light on the feasibility of translating these technologies into a clinically relevant treatment modality for HPV derived cancers and potentially other virally driven human cancers.
\end{abstract}

\section{Keywords}

siRNA; CRISPR; HPV; miRNA; lncRNA

\section{Introduction}


The host immune system is generally efficient at clearing HPV infections. In a situation where it is not, it can persist for years culminating in carcinogenesis [1]. Anogenital, uveal, oropharyngeal, and oesophageal cancers are caused by high-risk HPV types, particularly types 16 and 18 being the two most prevalent HPV-driven cancers, cervical (CC) and oropharyngeal squamous cell carcinoma (OPSCC) cancers [2-6]. Despite preventive vaccination and screening being widely available for cervical cancer, HPV continues to cause gynaecological based cancer deaths in women worldwide with 600,000 cases approximately in 2020 , ranking as the ninth most prevalent cancer [7]. Of more significance currently are head and neck cancers (HNCs), which rank as the seventh most prevalent cancer worldwide with an annual incidence rate of approximately 900,000 cases [7]. Around one third of HNCs are now established to be caused by persistent infection with high-risk HPV (hrHPV) type $16[8,9]$. Indeed, there is a strong association between hrHPV and OPSCC, a subset of HNCs, which has the fastest growing incidence rates among all cancers [10]. It is now the most common HPV-associated cancer, due to persistent infection with hrHPV type 16 [11]. Around $20 \%$ of HNCs do not respond to current treatments, have poor prognosis and its relationship to HPV-associated OPSCCs has had a recent dramatic increase in the past few years $[9,12,13]$, outnumbering cervical disease in various countries, in particular the USA $[14,15]$. Current HPV cancer treatment modalities include surgery or concurrent chemoradiation or both. These treatments have saved many lives, but patient outcomes often remain almost the same with poor prognosis and patient survival [16-18]. Because the process of carcinogenesis takes years, there is a gap for clinical prevention, diagnosis, and treatment that researchers are striving to take advantage of with the development of novel and gene-specific therapies. Here, we aim to review emerging RNA-based gene targeting approaches that have been tested for HPV-driven cancers.

\section{Short-interfering RNA (siRNA)}


Sequence-specific short-interfering RNAs (siRNA) are typically 21 nucleotides double stranded RNAs with two base pair 3' overhangs and work by suppressing gene expression via directly degrading target gene mRNA in the cytosol (Figure 1). This leads to the loss of gene target protein expression, with high efficiency and specificity. Three siRNA formulations have been approved by the Food and Drug Administration (FDA) and are now licensed for clinical use: Givlaari (Givosiran) for acute hepatic porphyria (AHP), Onpattro (also known as Patisiran) for hereditary transthyretin-mediated amyloidosis (hATTR) [19], and lumasiran (Oxlumo), for primary hyperoxaluria type 1 . Indeed, siRNAs holds the potential as an RNA interference (RNAi)-based therapeutic agent for a range of cancers, including HPV-driven cancers.

Multiple HPV genes have been targeted experimentally for the purposes of therapy, particularly early non-structural genes E1, E2, E4, E5, E6 and E7. HPV frequently integrates into the host genome disrupting gene E2 repressor activity and in every cell cycle, the two notorious oncoproteins, E6 and E7, replicate continuously [20]. E6 and E7 are the most attractive targets as these oncogenes are known to be the main drivers of carcinogenesis. E6 exerts its effect by degrading p53, a tumour suppressor, which makes cells lose control of the mitotic cell cycle in G2/M checkpoint, whereas E7 inactivates phosphorylated retinoblastoma protein (pRb), taking the brakes off the cell cycle and thereby allowing cells to proliferate uncontrollably [21]. Since both genes are expressed from the same promoter, E6 and E7 are found together on the same mRNA transcript, though this differs between HPV types. siRNAs have been shown to reduce E6 and E7 expression, resulting in the subsequent restoration of $\mathrm{p} 53$ and $\mathrm{Rb}$ function respectively, to induce reduction of tumour growth, and cellular apoptosis or senescence or both (Table 1). Early work attempting to silence E6 and E7 in vitro using siRNAs were done in HPV positive $\left({ }^{+}\right)$ $\mathrm{CC}$ cell lines, CaSki and SiHa [22]. Knockdown of E6 induced accumulation of p53 and reduced 
cell growth, while E7 loss drove cells to undergo apoptosis. Since then, numerous studies have examined this strategy to target cancer cell and tumour growth (Table 1). The majority of studies reported effective tumour reduction with siRNA treatment targeting E6 and E7, demonstrating that oncogene targeting siRNAs are highly specific and able to reverse the biological effects of these oncogenes. An effective method for delivering these siRNAs is critical for this therapy to be clinically valid. siRNAs are too large and hydrophilic to travel across the cell membrane. Instead, they must be able to enter target cells to be released into the cytoplasm to knockdown the target mRNA. When administered, siRNAs have to go through numerous host obstacles, including innate immune system recognition, nucleases, non-specific interaction with serum proteins and nontarget cells, renal clearance, cell entry, exit from blood vessels to reach target tissues and incorporation into the RNAi system. Over the last two decades, a number of nano-delivery technologies have been developed to surpass these obstacles, which can be improved with chemical modification, nanoparticle complexation and addition of targeting moieties [23-26]. However, this can be overcomed with novel nanoparticle formulations, which have been tested for vaginal, intravenous, and intraperitoneal delivery of siRNAs in animal models for HPV cancers [27-31]. siRNA delivery using lentiviruses in HPV cancer animal models have also been done though the feasibility of using this platform in humans remain debatable and its clinical use have been limited to ex vivo gene therapy settings [32,33].

\section{CRISPR gene editing technology}

Targeted genome editing technologies using programmable endonucleases is a rapidly evolving field. The most well-known system is the clustered, regularly interspaced, short palindromic repeats (CRISPR) associated endonuclease system. The best characterised CRISPR system uses Cas protein 9 (Cas9) (type II), which induces double stranded breaks (DSB) at specific sites of the 
target DNA. Cas9 protein uses dual RNA, or guide RNA (gRNA), for site specific DNA cleavage. After cleavage, the DSBs are repaired by either the error prone non-homologous end joining (NHEJ) pathway, or the high-fidelity homology directed repair (HDR) pathway [34]. More recently, Cas13a (type VI) has also been employed in the CRISPR system to knockdown specific mRNAs [35]. CRISPR technology can be harnessed to generate loss-of-function or gain-offunction mutations in tumour suppressor genes, oncogenes or other modulators of gene expression. CRISPR can also be used to activate genes by inactivating the Cas proteins (dCas) and adding transcriptional activation domains (CRISPRa) [36].

The use of CRISPR mediated therapy for HPV cancers have been explored (Table 2). In the case of $\mathrm{CC}$, tumours rely entirely on the continuous expression of both E6 and E7 proteins to survive [21], which renders these proteins an ideal therapeutic target. In HPV cervical cell lines, targeting E6 and E7 genes with CRISPR restored p53 and pRb cellular levels respectively, resulting in cell death and apoptosis $[37,38]$. The same effect was also observed in vitro, where CRISPR knockdown of E6 and E7 genes led to inhibition of tumour growth [39]. Recently, another study delivered, nanoparticles with CRISPR targeting E6 or E7 completely ablated tumours in a CC xenograft in vitro model [40] further emphasising that these cervical HPV tumours are "oncogene addicted".

Other strategies knocking out E6 and E7 expression by targeting their common early promoter region, p97, have been attempted using CRISPR [39]. Given that the length of both E6 and E7 genes are short, choosing unique target sequences within these genes can be challenging. Hence, the notion of targeting other regulatory regions might serve as an alternative strategy. In fact, HPV gene expression is largely regulated at the post-transcriptional level, including RNA processing, nuclear export, mRNA stability and translation, in addition to several early and late promoters 
controlling the expression at the transcriptional level. Therefore, interrupting these regulatory networks may also be exploited therapeutically. CRISPR-based therapies could also be designed to target the region extending from the end of the $\mathrm{L} 1$ open reading frame (ORF) to the late 3 ' untranslated region (UTR), the region that encodes for key RNA stability regulators that preclude the expression of the HPV capsid proteins. Because these capsid proteins are highly immunogenic, restoring its expression would trigger a robust immune response, thus leading to the clearance of the virus [41]. Beside the early and late promoters, several other promoters have been described in various HPV genomes; such as a late promoter located at the beginning of E4 ORF, which regulates the expression of L1 capsid protein [42], and one located at E5 ORF that encodes for L2 as a first ORF [42]. However, exploiting these regulatory pathways to enhance virus clearance or interrupt gene expression remains hindered by our limited understanding of the molecular interactions involving multiple genomic regions.

The concept of reactivating p53 via CRISPRa, as a way of overcoming E6 mediated inactivation of $\mathrm{p} 53$, has yet to be tested but might prove an excellent approach. Tumour suppressor p53 plays an essential role in preventing HPV mediated tumorigenesis. The use of p53 as a gene therapy target for $\mathrm{CC}$ has been extensively explored due to the high percentage of p53 inactivation present [43]. As a proof of concept, overcoming p53 inactivation has been shown to work when in vitro mediated p53 protein delivery leads to apoptosis, cell cycle arrest and suppression of cell migration and invasion in HeLa cells [44]. As demonstrated in a range of other CC cell lines (HeLa, SiHa and $\mathrm{C} 33 \mathrm{~A})$, recombinant adenovirus-p53 treatment inhibited cell growth and enhanced apoptosis by increasing the expression levels of exogenous p53 gene [45, 46]. A biological recombinant human p53 adenovirus gene therapy (Gendicine) was approved in 2003 by the China Food and Drug Administration (CFDA) to treat HNC patients. Gendicine transduces cells to express wild 
type p53 protein and is administered either as an intratumorally or intracavity injection or as an intravascular infusion [47]. Although initially approved to treat HNCs, Gendicine has been used to treat various other cancer types, including $\mathrm{CC}$ patients in combination with radiotherapy Though idea of knocking down mRNAs via siRNA was discussed earlier, the CRISPR-Cas13a system posseses a similar ability. This system has been tested in various cancers models, including pancreatic cancer to inhibit mutant KRAS mRNA expression, as well as inhibiting SMAD7 eRNA (mRNA enhanced by oestrogen) [48, 49]. In both cases cellular apoptosis occurred and significant tumour shrinkage was observed. CRISPR-Cas 13a has also been shown to cleave HVP 16/18 E6/E7 mRNAs in SiHa and HeLa cell lines and in SiHa xenograft tumours resulting in cell death and tumour regression [50]. CRISPR gene editing for HPV-driven cancers is a rapidly emerging field, which carries feasible clinical promise as a future therapy.

\section{Future and emerging RNA-based therapies for HPV cancers}

\section{Micro RNAs (miRNA)}

MiRNAs are single stranded endogenous non-coding small RNA molecules, approximately 19 to 22 nucleotides in length, involved in the regulation of gene expression. They are capable of posttranscriptional changes by binding to the 3' untranslated region of the target mRNA to either affect translation (appoint mRNAs for cleavage and avoid protein synthesis) or reduced mRNAs stability. miRNAs are known to have a role in various cancer related biological processes such as differentiation, apoptosis, proliferation, metabolism, invasion, metastasis, and drug resistance, which makes them function as either tumour suppressors or cancer promoters [51-55]. There are certain miRNAs that may also have an effect in the genes that control some anti-tumour responses making the miRNAs dysregulation somehow related to the origin of certain types of cancer [56]. 
Genome wide miRNA profiling has shown that there could be different expression patterns when certain miRNAs are present in various human infectious diseases such as Ebola virus, Coronavirus 19 (COVID-19), Human immunodeficiency virus (HIV) and Kaposi sarcoma-associated herpes virus, where latter two are have carcinogenic potential [57-60]. As a result, numerous studies that have used miRNAs as potential biomarkers for cancer diagnosis, prognosis, and cancer staging. miRNA profiles in HPV cancers have also been explored (Table 3). Briefly, miR-10b, miR-15a, miR-20b and miR-16 have been found to be upregulated and miR-139-3p, miR-145, miR-381 and miR-574-3p downregulated in CC and HNC HPV tumours [61]. However, the presence of certain miRNAs was more prevalent in some than other HPV cancer types. In CCs, miR-16, miR-20a, miR-21, miR-34a and miR-182 were more prevalent whereas in HNCs miR-9 is prevalent (Table 3). It was found that miR-16 in non-small cell lung cancer has the ability to induce cell cycle arrest in $\mathrm{G} 1-\mathrm{G} 0$ when $\mathrm{Rb}$ is present suggesting that this miRNA may be involved in cell cycle progression in HPV cancer [62]. miR-20a has been shown to be upregulated by HPV16 E6 in CC and promotes cell growth [63]. On the other hand, miR-21 is involved in post-transcriptional downregulation of the tumour suppressor gene, PTEN, to promote cell proliferation and cancer survival [64]. Moreover, it was demonstrated that miR-34a was elevated either by HPV16 E7 or chronic levels of oestrogen, in early cancer stages, but it was downregulated when both factors were present in the late stages [65]. High-risk HPV E7 has been shown to upregulate miR-182 expression through the TGF- $\beta /$ Smad4 pathway, a pathway critical in cancer progression [66]. It is interesting to note that miR-9 is upregulated only in squamous cell carcinoma caused mainly by HPV16 promoting cell viability and anchorage independence, while in HPV18+ cells it plays a tumour suppressive role [67]. 
The use of miRNAs for targeting HPV cancers has been investigated but not to the degree that siRNAs have been used. Targeting HPV16/18 E6 mRNA with miRNAs in HeLa and SiHa cells resulted in apoptosis but failed to observe any regression in HeLa derived tumour growth in vitro [68]. Another study showed that inhibition of miR-93-5p, which regulates B-cell translocation gene 3 (BTG3) expression, blocks the proliferation, invasion and migration and promote apoptosis of HPV $+\mathrm{CC}$ cells, CaSki and HeLa [69]. It was also found that miR-3156-3p expression inhibited cell growth and promoted apoptosis in HPV18 (HeLa) and HPV16 (SiHa and CaSki) + cells [70]. Furtherrmore, it was also shown that miR-155-5p enhances autophagy of cancer cells by targeting the expression of PDK1 and inhibiting the Akt/mTOR signalling pathway [71]. In addition, overexpression of miR-10b in HeLa and $\mathrm{SiHa}$ repressed cell proliferation, migration, invasion, and induced apoptosis [72]. T-cell lymphoma invasion and metastasis 1 (Tiam1) is a direct and functional target of miR-10b which when suppressed by the miRNA acted as a tumour suppressor. In conclusion, there are potential miRNA candidates that could be utilised for HPV cancer therapy but further work to understand the use of miRNAs such setting is warranted. Despite all this, miRNAs have not been widely used to treat HPV infections because their mechanisms of action are not well understood and are still being studied. Only few miRNAs have been demonstrated to be altered in HPV-associated cancers. Therefore, it is likely that miRNAs will be initially used as biomarkers for $\mathrm{HPV}+$ cancers as further work is needed before moving forward with using miRNAs therapeutically.

\section{Long non-coding RNAs (lncRNA)}

lncRNAs are transcripts that range in size (100 - 100000 nucleotides) and are diverse in structure. They function either as primary or spliced transcripts, are polyadenylated or non-polyadenylated and can be found in either the nucleus or the cytoplasm. LncRNAs lack evident ORFs and 
sometimes can be transcribed by RNA polymerase II and/or III. LncRNAs are also less expressed than protein coding genes, though this depends on the cell type. LncRNAs are still being characterised as their exact function remains elusive. As with many ncRNAs, lncRNAs could serve as potential biomarkers for certain human diseases. including HPV cancers. Indeed, the role of lncRNAs in HPV-driven pathogenesis is well-known [73]. In the context of HNCs, 140 lncRNAs have been identified to be differentially expressed in HPV+ HNC samples compared to HPVHNC samples [74].

There is also an opportunity to analyse particular roles of certain lncRNAs and determine possible targets for targeted therapy. One group studied the expression and regulation of lncRNA T5CF-7 and miR-155 in HPV 18+ CC cells [75]. Knockdown of T5CF-7 inhibited the cell growth and that miR-155 overexpression reverses this. In another study, lncRNA SNGH8 was shown to induce $\mathrm{CC}$ cell proliferation and migration when it binds to enhancer of zeste homolog 2, nuclear regulatory protein (EZH2) and inhibits transcriptionally reversion inducing cysteine rich protein, stops angiogenesis (RECK) expression making SNGH8 a good target to directed therapy for CC [76]. Another study found an interplay between HPV16 E7 oncoprotein and lncRNA HOX antisense intergenic RNA (HOTAIR) [77]. E7 downregulates HOTAIR causing anomalies in the chromatin remodelling complex PRC2 (creating gene silencing H3K27 me3) alongside the cellular processes of cell proliferation and metastasis. Recent work has shown that the damage-induced lncRNA, DINO, that is known to bind and stabilise TP53, is expressed at low levels in a range of $\mathrm{HPV}+\mathrm{CC}$ cell lines as a result of HPV E6-mediated TP53 degradation [78]. Indeed, acute ectopic expression of DINO sensitises cells to standard-of-care CC chemotherapeutics, including cisplatin. lncRNA metastasis-associated lung adenocarcinoma transcript 1 (MALAT1) working alongside miR-124 and growth factor receptor-bound protein 2 (GRB2) was found to promote high-risk HPV 
cancers [79]. This suggests that lncRNAs do not work alone, as they can indirectly regulate mRNAs expression by trapping miRNAs acting as sponges for other RNAs to regulate metabolic pathways. However, there remains little evidence to support proposal of using lncRNAs for HPV cancer therapy. Further work is needed to explore this possibility. mRNA-based HPV vaccines

Current vaccines available for CC include, Cervarix ${ }^{\circledR}(\mathrm{HPV} 16,18)$, Gardasil4 ${ }^{\circledR}(\mathrm{HPV} 16,18,6$, 11), and Gardasi19® (HPV 6, 11, 16, 18, 31, 33, 45, 52, 58) and have shown to confer good protection [80]. This protection is mediated by neutralising antibodies generated against HPV L1 capsid protein, which are immunogenic [81]. Prophylactic vaccines currently available are not effective either when the infection is prevalent or has established intraepithelial lesions. In the carcinogenic stage, the microenvironment is immunosuppressed by HPV (particularly by E6 and E7) [82] and T-cells are either anergic or exhausted and fail to detect viral antigens. Hence the challenge is to create a therapeutic vaccine that generates cytotoxic T-lymphocytes that recognise HPV antigens.

Synthetic mRNA was first administered into mouse skeletal muscle in 1990 and demonstrated that it can express the target protein in cells [83]. The recent COVID-19 epidemic has led to the advent of the rapid development of mRNA vaccines. mRNA vaccines carry several advantages; it is safe (no virus/protein contamination or genome integration) and activates a strong adaptive immune response without the need for adjuvants. In the case of HPV, the putative targets are E6 and E7. HPV cancer vaccines, that target tumour associated antigens (E6 and E7), have been developed in the form of a lipidic protein with the mutant form of HPV16 E7 (rlipo-E7m) and has shown to inhibit tumour growth in mice [84]. A phase II trial of imiquimod and a HPV therapeutic vaccine 
(a fusion HPV16 E6E7L2 protein formulation called TA-CIN) in patients with vulval intraepithelial neoplasia reported complete regression of lesions in $63 \%$ of the patients [85].

In the future, the development of an mRNA vaccine for HPV cancers can utilise other oncoproteins (other than E6 and E7) or specific components of the virus making the vaccine safer, cheaper, and not only prophylactic but possibly therapeutic in cancer later stages.

\section{Conclusions}

Currently, the promise of genetic based treatments for HPV remains in preclinical stages. Promising results are clear and await support for clinical translation. mRNA vaccines for COVID19 are now a reality and can potentially be applied for HPV cancers. Given that the use of siRNAs as therapeutic agents have already reached the clinic for a number of diseases [19], this could potentially be a reality for HPV cancers. Using CRISPR as a potential therapeutic for HPV cancers may become a reality with the recent successful Phase I/II CRISPR-based therapy tested in patients with transthyretin amyloidosis (ATTR), a rare disease caused by the progressive accumulation of misfolded TTR protein in tissues [86]. Indeed, CRISPR gene editing of the TTR gene resulted in demonstrable loss of serum TTR protein in patients. Given that CC is "oncogenically addicted" to E6 and/or E7 [40], the use of CRISPR therapy to edit one of these oncogenes, could prove to be therapeutically feasible clinically. CRISPR could become a concomitant therapy to the standard treatment modality (surgery, radiation, and chemotherapy) for HPV cancers.

miRNAs and lncRNAs have been studied in a myriad of settings on HPV derived cancers. Initially proposed to be used soley as cancer biomarkers, it is becoming increasingly evident that miRNAs and lncRNAs could be utilised as therapeutic targets. Given that multiple miRNAs and lncRNAs play a role in HPV cancers, it seems clinically unfeasible to target multiple miRNAs and lncRNAs though it could possibly work when combined with standard treatment protocols 
for HPV cancers. In conclusion, nanoparticle/viral vector-based co-delivery of chemotherapy

drugs or radiotherapy with RNA-based gene targeting therapies offers a new alternative to start eliminating HPV derived cancers at present. The future of RNA-based gene targeting therapies for HPV cancers is exciting and much anticipation is expected with the advent of RNA-based therapies being deployed for COVID-19 in recent times.

\section{References}

[1] A.-B. Moscicki et al., "Updating the Natural History of Human Papillomavirus and Anogenital Cancers," Vaccine, vol. 30, 5, pp. F24-F33, 2012, doi: https://doi.org/10.1016/j.vaccine.2012.05.089.

[2] D. Forman et al., "Global Burden of Human Papillomavirus and Related Diseases," Vaccine, vol. 30, 5, pp. F12-F23, 2012, doi: https://doi.org/10.1016/j.vaccine.2012.07.055.

[3] B. Anand et al., "Prevalence of high-risk human papillomavirus genotypes in retinoblastoma," British Journal of Ophthalmology, vol. 95, pp. 1014-1018, 2011, doi: http://dx.doi.org/10.1136/bjo.2010.199802.

[4] I. Agalliu et al., "Oral Alpha, Beta, and Gamma HPV Types and Risk of Incident Esophageal Cancer," Cancer Epidemiology, Biomarkers \& Prevention, vol. 27, no. 10, pp. 1168-1175, 2018, doi: https://doi.org/10.1158/1055-9965.EPI-18-0287.

[5] A. K. Chalkia, G. Bontzos, D. A. Spandidos, and E. T. Detorakis, "Human papillomavirus infection and ocular surface disease (Review)," International Journal of Oncology, vol. 54, no. 5, pp. 1503-1510, 2019, doi: https://doi.org/10.3892/ijo.2019.4755.

[6] D. Bucchi, F. Stracci, N. Buonora, and G. Masanotti, "Human papillomavirus and gastrointestinal cancer: A review," World Journal of Gastroenterology, vol. 22, no. 33, pp. 7415-7430, 2016, doi: 10.3748/wjg.v22.i33.7415.

[7] H. Sung et al., "Global Cancer Statistics 2020: GLOBOCAN Estimates of Incidence and Mortality Worldwide for 36 Cancers in 185 Countries," CA: A Cancer Journal for Clinicians, vol. 7, no. 3, pp. 209-249, 2021, doi: https://doi.org/10.3322/caac.21660.

[8] G. D'Souza and A. Dempsey, "The role of HPV in head and neck cancer and review of the HPV vaccine," (in eng), Preventive medicine, vol. 53 Suppl 1, pp. S5-s11, Oct 2011, doi: https://doi.org/10.1016/j.ypmed.2011.08.001.

[9] A. K. Adams, T. M. Wise-Draper, and S. I. Wells, "Human papillomavirus induced transformation in cervical and head and neck cancers," (in eng), Cancers, vol. 6, no. 3, pp. 1793-820, Sep 15 2014, doi: https://doi.org/10.3390/cancers6031793.

[10] E. A. Van Dyne, J. Henley, M. Saraiya, C. C. Thomas, L. E. Markowitz, and V. B. Benard, "Trends in Human Papillomavirus-Associated Cancers-United States, 1999-2015," Morbidity and Mortality Weekly Report, vol. 67, no. 33, 2018, doi: http://dx.doi.org/10.15585/mmwr.mm6733a2.

[11] S. V. Bratman, J. P. Bruce, and B. O'Sullivan, "Human Papillomavirus Genotype Association With Survival in Head and Neck Squamous Cell Carcinoma," JAMA Oncology, vol. 2, no. 6, pp. 823-826, 2016, doi: 10.1001/jamaoncol.2015.6587. 
[12] T. Dalianis, "Human papillomavirus and oropharyngeal cancer, the epidemics, and significance of additional clinical biomarkers for prediction of response to therapy (Review)," (in eng), International Journal of Oncology, vol. 44, no. 6, pp. 1799-805, Jun 2014, doi: https://doi.org/10.3892/ijo.2014.2355.

[13] N. Osazuwa-Peters et al., "Sexual behavior, HPV knowledge, and association with head and neck cancer among a high-risk group," (in eng), Oral Oncology, vol. 51, no. 5, pp. 452-6, May 2015, doi: https://doi.org/10.1016/j.oraloncology.2015.01.011.

[14] S. Marur and A. A. Forastiere, "Head and Neck Squamous Cell Carcinoma: Update on Epidemiology, Diagnosis, and Treatment," Mayo Clinic Proceedings, vol. 91, no. 3, pp. 386-396, 2016, doi: http://dx.doi.org/10.1016/j.mayocp.2015.12.017.

[15] A. K. Chaturvedi et al., "Worldwide Trends in Incidence Rates for Oral Cavity and Oropharyngeal Cancers," Journal of Clinical Oncology, vol. 31, no. 36, pp. 4550-4559, 2013, doi: https://doi.org/10.1200/JCO.2013.50.3870.

[16] W.-J. Koh et al., "Cervical Cancer, Version 3.2019, NCCN Clinical Practice Guidelines in Oncology," Official Journal of the National Comprehensive Cancer Network, vol. 17, no. 1, 2019, doi: https://doi.org/10.6004/jnccn.2019.0001.

[17] C. Chu and D. G. Pfister, "Opportunities and Challenges: Human Papillomavirus and Cancer," Official Journal of the National Comprehensive Cancer Network, vol. 15, no. 5, 2017, doi: https://doi.org/10.6004/jncen.2017.0085.

[18] E. M. Sturgis and K. K. Ang, "The Epidemic of HPV-Associated Oropharyngeal Cancer Is Here: Is It Time to Change Our Treatment Paradigms?," Official Journal of the National Comprehensive Cancer Network, vol. 9, no. 6, 2011, doi: https://doi.org/10.6004/jnccn.2011.0055.

[19] P. E. Saw and E.-W. Song, "siRNA therapeutics: a clinical reality," Science China Life Sciences, vol. 63, no. 4, pp. 485-500, 2020, doi: https://doi.org/10.1007/s11427-018-9438$\mathrm{y}$.

[20] H. Romanczuk and P. M. Howley, "Disruption of either the E1 or the E2 regulatory gene of human papillomavirus type 16 increases viral immortalization capacity," Procedings of the National Academy of Sciences of the United States of America, vol. 89, no. 7, pp. 31593163, 1991, doi: https://doi.org/10.1073/pnas.89.7.3159.

[21] K. Münger, W. C. Phelps, V. Bubb, P. M. Howley, and R. Schlegel, "The E6 and E7 Genes of the Human Papillomavirus Type 16 Together Are Necessary and Sufficient for Transformation of Primary Human Keratinocytes," Journal of Virology, vol. 63, no. 10, 1989.

[Online]. Available: https://www.ncbi.nlm.nih.gov/pmc/articles/PMC251060/pdf/jvirol00077-0309.pdf.

[22] M. Jiang and J. Milner, "Selective silencing of viral gene expression in HPV-positive human cervical carcinoma cells treated with siRNA, a primer of RNA interference," Oncogene, vol. 21, pp. 6041-6048, 2002, doi: https://doi.org/10.1038/sj.onc.1205878.

[23] G. R. Devi, "siRNA-based approaches in cancer therapy," Cancer Gene Therapy, vol. 13, pp. 819-829, 2006, doi: https://doi.org/10.1038/sj.cgt.7700931.

[24] R. Kanasty, J. R. Dorkin, A. Vegas, and D. Anderson, "Delivery materials for siRNA therapeutics," Nature Materials, vol. 12, pp. 967-977, 2013, doi: https://doi.org/10.1038/nmat3765.

[25] Q. Lin, J. Chen, Z. Zhang, and G. Zheng, "Lipid-based nanoparticles in the systemic delivery of siRNA," Nanomedicine, vol. 9, no. 1, 2013, doi: https://doi.org/10.2217/nnm.13.192. 
[26] A. A. Seyhan, "RNAi: a potential new class of therapeutic for human genetic disease," Human Genetics, vol. 130, no. 583-605, 2011, doi: https://doi.org/10.1007/s00439-0110995-8.

[27] S. Y. Wu and N. A. McMillan, "Lipidic systems for in vivo siRNA delivery," The AAPS Journal, vol. 11, no. 4, pp. 639-52, Dec 2009, doi: https://doi.org/10.1208/s12248-0099140-1.

[28] A. Singhania, S. Y. Wu, and N. A. J. McMillan, "Effective Delivery of PEGylated siRNAContaining Lipoplexes to Extraperitoneal Tumours following Intraperitoneal Administration," Journal of Drug Delivery, vol. 2011, 2011, Art no. 192562, doi: https://doi.org/10.1155/2011/192562.

[29] S. Y. Wu, H. I. Chang, M. Burgess, and N. A. McMillan, "Vaginal delivery of siRNA using a novel PEGylated lipoplex-entrapped alginate scaffold system," Journal of Controlled Release, vol. 155, no. 3, pp. 418-26, Nov 7 2011, doi: 10.1016/j.jconrel.2011.02.002.

[30] A. Idris et al., "A SARS-CoV-2 targeted siRNA-nanoparticle therapy for COVID-19," Molecular Therapy, vol. 29, no. 7, 2021, doi: https://doi.org/10.1016/j.ymthe.2021.05.004.

[31] S. Y. Wu et al., "Systemic delivery of E6/7 siRNA using novel lipidic particles and its application with cisplatin in cervical cancer mouse models," Gene Therapy, vol. 18, no. 1, pp. 14-22, 2011, doi: https://doi.org/10.1038/sj.cgt.7700971.

[32] W. Gu et al., "Inhibition of cervical cancer cell growth in vitro and in vivo with lentiviralvector delivered short hairpin RNA targeting human papillomavirus E6 and E7 oncogenes," Cancer Gene Ther, vol. 13, no. 11, pp. 1023-32, Nov 2006, doi: https://doi.org/10.1038/sj.cgt.7700971.

[33] L. N. Putral et al., "RNA Interference against Human Papillomavirus Oncogenes in Cervical Cancer Cells Results in Increased Sensitivity to Cisplatin," Molecular Pharmacology, vol. 68, no. 5, pp. 1311-1319, 2005, doi: https://doi.org/10.1124/mol.105.014191.

[34] F. J. Sánchez-Rivera and T. Jacks, "Applications of the CRISPR-Cas9 system in cancer biology," Nature reviews. Cancer, vol. 15, no. 7, pp. 387-395, 06/04 2015, doi: https://doi.org/10.1038/nrc3950.

[35] O. O. Abudayyeh et al., "C2c2 is a single-component programmable RNA-guided RNAtargeting CRISPR effector," Science, vol. 353, no. 6299, 2016, doi: https://doi.org/10.1126/science.aaf5573.

[36] M. L. Maeder, S. J. Linder, V. M. Cascio, Y. Fu, Q. H. Ho, and J. K. Joung, "CRISPR RNA-guided activation of endogenous human genes," Nature methods, vol. 10, pp. 977979, 2013, doi: https://doi.org/10.1038/nmeth.2598.

[37] E. M. Kennedy et al., "Inactivation of the Human Papillomavirus E6 or E7 Gene in Cervical Carcinoma Cells by Using a Bacterial CRISPR/Cas RNA-Guided Endonuclease," Journal of Virology, vol. 88, no. 20, pp. 11965-11972, 2014, doi: https://doi.org/10.1128/JVI.01879-14.

[38] Z. Hu et al., "Disruption of HPV16-E7 by CRISPR/Cas System Induces Apoptosis and Growth Inhibition in HPV16 Positive Human Cervical Cancer Cells," BioMed research international, vol. 2014, no. 612823, p. 9, 2014, doi: https://doi.org/10.1155/2014/612823.

[39] S. Zhen, L. Hua, Y. Takahashi, S. Narita, Y.-H. Liu, and Y. Li, "In vitro and in vivo growth suppression of human papillomavirus 16-positive cervical cancer cells by CRISPR/Cas9," (in eng), Biochemical and Biophysical Research Communications, vol. 450, no. 4, pp. 1422-1426, Aug 8 2014, doi: https://doi.org/10.1016/j.bbrc.2014.07.014. 
[40] L. Jubair, S. Fallaha, and N. A. J. McMillan, "Systemic Delivery of CRISPR/Cas9 Targeting HPV Oncogenes is Effective at Eliminating Established Tumors," Molecular Therapy, vol. 27, no. 12, pp. 2091-2099, 2019, doi: https://doi.org/10.1016/j.ymthe.2019.08.012.

[41] S. V. Graham, "Human papillomavirus: gene expression, regulation and prospects for novel diagnostic methods and antiviral therapies," Future Microbiology, vol. 5, no. 10, pp. 1493-1506, 2010, doi: https://doi.org/10.2217/fmb.10.107.

[42] S. G. Milligan, T. Veerapraditsin, B. Ahamet, S. Mole, and S. V. Graham, "Analysis of novel human papillomavirus type 16 late mRNAs in differentiated W12 cervical epithelial cells," (in eng), Virology, vol. 360, no. 1, pp. 172-81, Mar 30 2007, doi: https://doi.org/10.1016/j.virol.2006.10.012.

[43] J. Doorbar, "Molecular biology of human papillomavirus infection and cervical cancer," (in eng), Clinical Science (London), vol. 110, no. 5, pp. 525-41, May 2006, doi: https://doi.org/10.1042/CS20050369.

[44] H. Han et al., "Inhibition of cell proliferation and migration through nucleobase-modified polyamidoamine-mediated p53 delivery," (in eng), International journal of nanomedicine, vol. 13, pp. 1297-1311, 2018, doi: https://doi.org/10.2147/IJN.S146917.

[45] Y. G. Liu, X. L. Zheng, and F. M. Liu, "The mechanism and inhibitory effect of recombinant human P53 adenovirus injection combined with paclitaxel on human cervical cancer cell HeLa," (in eng), European Review for Medical and Pharmacological Sciences, vol. 19, no. 6, pp. 1037-42, 2015.

[46] X. Su et al., "Effect and Safety of Recombinant Adenovirus-p53 Transfer Combined with Radiotherapy on Long-Term Survival of Locally Advanced Cervical Cancer," (in eng), Human gene therapy, vol. 27, no. 12, pp. 1008-1014, Dec 2016, doi: https://doi.org/10.1089/hum.2016.043.

[47] W.-W. Zhang et al., "The First Approved Gene Therapy Product for Cancer Ad-p53 (Gendicine): 12 Years in the Clinic," Human gene therapy, vol. 29, no. 2, pp. 160-179, 2018/02/01 2018, doi: https://doi.org/10.1089/hum.2017.218.

[48] X. Zhao et al., "A CRISPR-Cas13a system for efficient and specific therapeutic targeting of mutant KRAS for pancreatic cancer treatment," Cancer Letters, vol. 431, pp. 171-181, 2018, doi: https://doi.org/10.1016/j.canlet.2018.05.042.

[49] W. Che, S. Ye, A. Cai, X. Cui, and Y. Sun, "CRISPR-Cas13a Targeting the Enhancer RNA-SMAD7e Inhibits Bladder Cancer Development Both in vitro and in vivo," Frontiers in Molecular Biosciences, vol. 7, no. 607740, 2020, doi: https://doi.org/10.3389/fmolb.2020.607740.

[50] Y. Chen et al., "In vitro and in vivo growth inhibition of human cervical cancer cells via human papillomavirus E6/E7 mRNAs' cleavage by CRISPR/Cas13a system," Antiviral Research, vol. 178, 2020, doi: https://doi.org/10.1016/j.antiviral.2020.104794.

[51] I. A. Asangani et al., "MicroRNA-21 (miR-21) post-transcriptionally downregulates tumor suppressor Pdcd4 and stimulates invasion, intravasation and metastasis in colorectal cancer," Oncogene, vol. 27, pp. 2128-2136, 2008, doi: https://doi.org/10.1038/sj.onc. 1210856 .

[52] Y. Hayashita et al., "A Polycistronic MicroRNA Cluster, miR-17-92, Is Overexpressed in Human Lung Cancers and Enhances Cell Proliferation," Cancer Research, vol. 65, no. 21, 2005, doi: 10.1158/0008-5472.CAN-05-2352. 
[53] T. Li, D. Li, J. Sha, P. Sun, and Y. Huang, "MicroRNA-21 directly targets MARCKS and promotes apoptosis resistanceand invasion in prostate cancer cells," Biochemical and Biophysical Research Communications, vol. 383, no. 3, pp. 280-285, 2009, doi: https://doi.org/10.1016/j.bbrc.2009.03.077.

[54] L. Ma, J. Teruya-Feldstein, and R. A. Weinberg, "Tumour invasion and metastasis initiated by microRNA-10b in breast cancer," Nature, vol. 449, pp. 682-688, 2007, doi: https://doi.org/10.1038/nature06174.

[55] B. C. Snoek, I. Babion, D. Koppers-Lalic, D. M. Pegtel, and R. D. M. Steenbergen, "Altered microRNA processing proteins in HPV-induced cancers," Current Opinion in Virology, vol. 39, pp. 23-32, 2019, doi: https://doi.org/10.1016/j.coviro.2019.07.002.

[56] E. Tili, J.-J. Michaille, and C. M. Croce, "MicroRNAs play a central role in molecular dysfunctions linking inflammation with cancer," Immunological reviews, vol. 253, no. 1, pp. 167-184, 2013, doi: https://doi.org/10.1111/imr.12050.

[57] Z.-Y. Wang et al., "Genome-Wide Search for Competing Endogenous RNAs Responsible for the Effects Induced by Ebola Virus Replication and Transcription Using a trVLP System," Frontiers in Cellular and Infection Microbiology, vol. 7, no. 479, 2017, doi: https://doi.org/10.3389/fcimb.2017.00479.

[58] A.-A.-K. Khan, R. U. Sany, S. Islam, A. Bashar, and K. Islam, "Epigenetic Regulator miRNA Pattern Differences Among SARS-CoV, SARS-CoV-2, and SARS-CoV-2 WorldWide Isolates Delineated the Mystery Behind the Epic Pathogenicity and Distinct Clinical Characteristics of Pandemic COVID-19," Frontiers in Genetics, vol. 11, no. 765, 2020, doi: https://doi.org/10.3389/fgene.2020.00765.

[59] P. Gupta et al., "Genome-wide mRNA and miRNA analysis of peripheral bloodmononuclear cells (PBMC) reveals different miRNAs regulatingHIV/HCV coinfection," Virology, vol. 450-451, pp. 336-349, 2014, doi: https://doi.org/10.1016/j.virol.2013.12.026.

[60] R. Strahan, T. Uppal, and S. Verma, "Next-Generation Sequencing in the Understanding of Kaposi's Sarcoma-Associated Herpesvirus (KSHV) Biology," Viruses, vol. 8, no. 4, p. 92, 2016, doi: https://doi.org/10.3390/v8040092.

[61] C. Lajer et al., "The role of miRNAs in human papilloma virus (HPV)-associated cancers: bridging between HPV-related head and neck cancer and cervical cancer," British Journal of Cancer, vol. 103, pp. 1526-1534, 2012, doi: https://doi.org/10.1038/bjc.2012.109.

[62] N. Bandi et al., "miR-15a and miR-16 Are Implicated in Cell Cycle Regulation in a RbDependent Manner and Are Frequently Deleted or Down-regulated in Non-Small Cell Lung Cancer," Cancer Research, vol. 69, no. 13, pp. 5553-5559, 2009, doi: https://dx.doi.org/10.1158/0008-5472.CAN-08-4277.

[63] X. Liu, "Up-regulation of miR-20a by HPV16 E6 exerts growth-promoting effects by targeting PDCD6 in cervical carcinoma cells," Biomedicine \& Pharmacotherapy, vol. 102, pp. 996-1002, 2018, doi: https://doi.org/10.1016/j.biopha.2018.03.154.

[64] O. Peralta-Zaragoza et al., "Relevance of miR-21 in regulation of tumor suppressor gene PTEN in human cervical cancer cells," BMC Cancer, vol. 16, 2016, doi: https://doi.org/10.1186/s12885-016-2231-3.

[65] R. Ocadiz-Delgado et al., "Expression of miR-34a and miR-15b during the progression of cervical cancer in a murine model expressing the HPV16 E7 oncoprotein," Journal of Physiology and Biochemistry, 2021, doi: https://doi.org/10.1007/s13105-021-00818-9. 
[66] J. Chen et al., "The high-risk HPV oncogene E7 upregulates miR-182 expression through the TGF- $\beta$ /Smad pathway in cervical cancer," Cancer Letters, vol. 460, pp. 75-85, 2019, doi: https://doi.org/10.1016/j.canlet.2019.06.015.

[67] I. Babion, A. Jaspers, A. P. van Splunter, I. A. E. van der Hoorn, S. M. Wilting, and R. D. M. Steenbergen, "miR-9-5p Exerts a Dual Role in Cervical Cancer and Targets Transcription Factor TWIST1," Cells, vol. 9, no. 1, 2019, doi: https://doi.org/10.3390/cells9010065.

[68] A. C. Bonetta, L. Mailly, E. Robinet, G. Travé, M. Masson, and F. Deryckere, "Artificial microRNAs against the viral E6 protein provoke apoptosis in HPV positive cancer cells," Biochemical and Biophysical Research Communications, vol. 465, no. 4, pp. 658-664, 2015, doi: https://doi.org/10.1016/j.bbrc.2015.07.144.

[69] J. Li et al., "Suppression of miR-93-5p inhibits high-risk HPV-positive cervical cancer progression via targeting of BTG3," Human Cell, vol. 32, pp. 160-171, 2019, doi: https://doi.org/10.1007/s13577-018-00225-1.

[70] Y.-F. Xia et al., "miR-3156-3p is downregulated in HPV-positive cervical cancer and performs as a tumor-suppressive miRNA," Virology Journal, vol. 14, no. 20, 2017, doi: https://doi.org/10.1186/s12985-017-0695-7.

[71] F. Wang et al., "MiR-155-5p inhibits PDK1 and promotes autophagy via the mTOR pathway in cervical cancer," The International Journal of Biochemistry \& Cell Biology, vol. 99, pp. 91-99, 2018, doi: https://doi.org/10.1016/j.biocel.2018.04.005.

[72] M. Yu et al., "miR-10b Downregulated by DNA Methylation Acts as a Tumor Suppressor in HPV-Positive Cervical Cancer via Targeting Tiam1," Cellular Physiology and Biochemistry, vol. 51, no. 4, 2018, doi: https://doi.org/10.1159/000495680.

[73] S. Sharma and K. Munger, "The Role of Long Noncoding RNAs in Human Papillomavirusassociated Pathogenesis," Pathogens, vol. 9, no. 4, p. 289, 2020, doi: https://doi.org/10.3390/pathogens9040289.

[74] N. Nohata, M. C. Abba, and J. S. Gutkind, "Unraveling the oral cancer lncRNAome: Identification of novel lncRNAs associated with malignant progression and HPV infection," Oral Oncology, vol. 59, pp. 58-66, 2016, doi: http://dx.doi.org/10.1016/j.oraloncology.2016.05.014.

[75] Y. Z. Chen, J. W. Wang, F. C. Meng, P. yang, X. G. Zhang, and H. Z. Wu, "LncRNATCF7 up-regulates DNMT1 mediated by HPV-18 E6 and regulates biological behavior of cervical cancer cells by inhibiting miR-155," European Review for Medical and Pharmacological Sciences, vol. 23, no. 20, pp. 8779-8787, 2019, doi: 10.26355/eurrev_201910_19272.

[76] X. Qu, Y. Li, L. Wang, N. Yuan, M. Ma, and Y. Chen, "LncRNA SNHG8 accelerates proliferation and inhibits apoptosis in HPV-induced cervical cancer through recruiting EZH2 to epigenetically silence RECK expression," Journal of Cellular Biochemistry, vol. 121, pp. 4120-4129, 2019, doi: https://doi.org/10.1002/jcb.29646.

[77] S. Sharma et al., "Bridging Links between Long Noncoding RNA HOTAIR and HPV Oncoprotein E7 in Cervical Cancer Pathogenesis," Scientific Reports, vol. 5, no. 11724, 2015, doi: https://doi.org/10.1038/srep11724.

[78] S. Sharma and K. Munger, "Expression of the Long Noncoding RNA DINO in Human Papillomavirus-Positive Cervical Cancer Cells Reactivates the Dormant TP53 Tumor Suppressor through TM/CHK2 
Signaling," Molecular Biology and Physiology, vol. 11, no. 3, pp. e01190-20, 2020, doi: https://doi.org/10.1128/mBio.01190-20.

[79] S. Liu, L. Song, S. Zeng, and L. Zhang, "MALAT1-miR-124-RBG2 axis is involved in growth and invasion of HR-HPV-positive cervical cancer cells," Tumor Biology: the journal of the International Society for Oncodevelopmental Biology and Medicine, vol. 37, pp. 633-640, 2016, doi: https://doi.org/10.1007/s13277-015-3732-4.

[80] K. T. Clark and C. L. Trimble, "Current status of therapeutic HPV vaccines," Gynecologic Oncology, vol. 156, no. 2, pp. 503-510, 2020, doi: https://doi.org/10.1016/j.ygyno.2019.12.017.

[81] P. M. Day et al., "In Vivo Mechanisms of Vaccine-Induced Protection against HPV Infection," Cell Host \& Microbe, vol. 8, no. 3, pp. 260-270, 2010, doi: https://doi.org/10.1016/j.chom.2010.08.003.

[82] P. Kuo, S. M. Teoh, Z. K. Tuong, G. R. Leggatt, S. R. Mattarollo, and I. H. Frazer, "Recruitment of Antigen Presenting Cells to Skin Draining Lymph Node From HPV16E7Expressing Skin Requires E7-Rb Interaction," Frontiers in Immunology, vol. 9, p. 2896, 2018, doi: https://doi.org/10.3389/fimmu.2018.02896.

[83] J. A. Wolff et al., "Direct Gene Transfer into Mouse Muscle in Vivo," Science, vol. 247, no. 4949, pp. 1465-1468, 1990, doi: http://dx.doi.org/10.1126/science.1690918.

[84] Y.-P. Sher et al., "A therapeutic vaccine targeting HPV E6/E7 with intrinsic Toll-like receptor 2 agonist activity induces antitumor immunity," American Journal of Cancer Research, vol. 8, no. 12, pp. 2528-2537, 2018. [Online]. Available: https://www.ncbi.nlm.nih.gov/pmc/articles/PMC6325468/pdf/ajcr0008-2528.pdf.

[85] S. Daayana et al., "Phase II trial of imiquimod and HPV therapeutic vaccination in patients with vulval intraepithelial neoplasia," British Journal of Cancer, vol. 102, no. 7, 2010, doi: https://doi.org/10.1038/sj.bjc.6605611.

[86] J. D. Gillmore et al., "CRISPR-Cas9 In Vivo Gene Editing for Transthyretin Amyloidosis," New England Journal of Medicine, 2021, doi: https://www.nejm.org/doi/full/10.1056/NEJMoa2107454.

[87] L. Kampel et al., "Therapeutic inhibitory RNA in head and neck cancer via functional targeted lipid nanoparticles," Journal of Controlled Release, vol. 337, pp. 378-389, 2021, doi: https://doi.org/10.1016/j.jconrel.2021.07.034.

[88] C. Xu, W. Liu, Y. Hu, W. Li, and W. Di, "Bioinspired tumor-homing nanoplatform for codelivery of paclitaxel and siRNA-E7 to HPV-related cervical malignancies for synergistic therapy," Theranostics, vol. 10, no. 7, pp. 3325-3339, 2020, doi: https://doi.org/10.7150/thno.41228.

[89] S. B. Rho, S.-H. Lee, H.-J. Byun, B.-R. Kim, and C.-H. Lee, "IRF-1 Inhibits Angiogenic Activity of HPV16 E6 Oncoprotein in Cervical Cancer," International Journal of Molecular Sciences, vol. 21, no. 20, p. 7622, 2020, doi: https://doi.org/10.3390/ijms21207622.

[90] M. H. Shaikh et al., "Aurora kinases are a novel therapeutic target for HPV-positive head and neck cancers," Oral Oncology, vol. 86, pp. 105-112, 2018/11/01/ 2018, doi: https://doi.org/10.1016/j.oraloncology.2018.09.006.

[91] A. Lechanteur, T. Furst, B. Evrard, P. Delvenne, G. Piel, and P. Hubert, "Promoting Vaginal Distribution of E7 and MCL-1 siRNA-Silencing Nanoparticles for Cervical Cancer Treatment," Molecular Pharmaceutics, vol. 14, p. 1706-1717, 2017, doi: https://doi.org/10.1021/acs.molpharmaceut.6b01154. 
[92] N. Rajasekaran et al., "Effect of HPV E6/E7 siRNA with Chemotherapeutic Agents on the Regulation of TP53/E2F Dynamic Behavior for Cell Fate Decisions," Neoplasia, vol. 19, no. 10, pp. 735-749, 2017, doi: https://doi.org/10.1016/j.neo.2017.07.005.

[93] H. Nishida et al., "Systemic delivery of siRNA by actively targeted polyion complex micelles for silencing the E6 and E7 human papillomavirus oncogenes," Journal of Controlled Release, vol. 231, pp. 29-37, 2016, doi: https://doi.org/10.1016/i.jconrel.2016.03.016.

[94] R. M. Levine, C. V. Dinh, M. A. Harris, and E. Kokkoli, "Targeting HPV-infected cervical cancer cells with PEGylated liposomes encapsulating siRNA and the role of siRNA complexation with polyethylenimine," Bioengineering \& translational medicine, vol. 1, no. 2, pp. 168-180, 2016, doi: https://doi.org/10.1002/btm2.10022.

[95] J.-g. Li, L. Li, S.-w. Zhang, and X. Wei, "HPV16E7-Specific siRNA Inhibits Cell Proliferation in CaSki Cells," Cell Biochemistry and Biophysics, vol. 71, pp. 529-534, 2015, doi: https://doi.org/10.1007/s12013-014-0223-y.

[96] H. Chapoy-Villanueva, I. Martinez-Carlin, G. Lopez-berestein, and A. Chavez-Reyes, "Therapeutic silencing of HPV 16 E7 by systemic administration of siRNA-neutral DOPC nanoliposome in a murine cervical cancer model with obesity," JBUON, vol. 20, no. 6, pp. 1471-1479, 2015. [Online]. Available: https://www.jbuon.com/archive/20-6-1471.pdf.

[97] H. S. Jung et al., "Human Papillomavirus E6/E7-Specific siRNA Potentiates the Effect of Radiotherapy for Cervical Cancer in Vitro and in Vivo," International Journal of Molecular Sciences, vol. 16, no. 6, pp. 12243-12260, 2015, doi: https://doi.org/10.3390/ijms160612243.

[98] N. Khairuddin et al., "In vivo comparison of local versus systemic delivery of immunostimulating siRNA in HPV-driven tumours," Immunology and Cell Biology, vol. 92, pp. 156-163, 2014, doi: https://doi.org/10.1038/icb.2013.75.

[99] Z. Adhim et al., "Gene silencing with siRNA targeting E6/E7 as a therapeutic intervention against head and neck cancer-containing HPV16 cell lines," Acta Oto-Laryngologica, vol. 133, no. 7, pp. 761-771 2013, doi: https://doi.org/10.3109/00016489.2013.773405.

[100] B. Cun et al., "Cell growth inhibition in HPV 18 positive uveal melanoma cells by E6/E7 siRNA," Tumor Biology: the journal of the International Society for Oncodevelopmental Biology and Medicine, vol. 34, no. 3, pp. 1801-1806, 2013, doi: https://doi.org/10.1007/s13277-013-0719-x.

[101] J. Zhou et al., "Inhibition of cervical cancer cell growth in vitro and in vivo by lentiviralvector mediated shRNA targeting the common promoter of HPV16 E6 and E7 oncogenes," Antiviral Research, vol. 98, no. 2, pp. 305-313, 2013, doi: https://doi.org/10.1016/j.antiviral.2013.03.010.

[102] J. Yang, S. Li, F. Guo, W. Zhang, Y. Wang, and Y. Pan, "Induction of apoptosis by chitosan/HPV16 E7 siRNA complexes in cervical cancer cells," Molecular Medicine Sports, vol. 7, no. 3, pp. 998-1002, 2013, doi: https://doi.org/10.3892/mmr.2012.1246.

[103] J. Zhou et al., "Transcriptional gene silencing of HPV16 E6/E7 induces growth inhibition via apoptosis in vitro and in vivo," Gynecologic Oncology, vol. 124, no. 2, pp. 296-302, 2012, doi: https://doi.org/10.1016/j.ygyno.2011.10.028.

[104] H. S. Jung et al., "The synergistic therapeutic effect of cisplatin with Human Papillomavirus E6/E7 short interfering RNA on cervical cancer cell lines in vitro and in vivo," International Journal of Cancer, vol. 130, no. 8, pp. 1925-1936, 2012, doi: https://doi.org/10.1002/ijc.26197. 
[105] J.-C. Chang et al., "Highly potent and specific siRNAs against E6 or E7 genes of HPV16or HPV18-infected cervical cancers," Cancer Gene Therapy, vol. 17, pp. 827-836, 2010, doi: https://doi.org/10.1038/cgt.2010.38.

[106] D. Hong, W. Lu, F. Ye, and X. Xie, "Gene silencing of HPV16 E6/E7 induced by promotertargeting siRNA in SiHa cells," British Journal of Cancer, vol. 101, pp. 1798 - 1804, 2009, doi: https://doi.org/10.1038/sj.bjc.6605344.

[107] A. L. Jonson, L. M. Rogers, S. Ramakrishnan, and L. S. Downs Jr., "Gene silencing with siRNA targeting E6/E7 as a therapeutic intervention in a mouse model of cervical cancer," Gynecologic Oncology, vol. 111, 2008, doi: https://doi.org/10.1016/j.ygyno.2008.06.033.

[108] K. Yamato et al., "New highly potent and specific E6 and E7 siRNAs for treatment of HPV16 positive cervical cancer," Cancer Gene Therapy, vol. 15, pp. 140-153, 2008, doi: https://doi.org/10.1038/sj.cgt.7701118.

[109] C.-1. Nie, G.-1. Gao, J. Han, H. Li, H.-p. Chen, and M. He, "Human papillomavirus 16 E6, E7 siRNAs inhibit proliferation and induce apoptosis of SiHa cervical cancer cells," Chinese Journal of Cancer Research, vol. 20, no. 4, pp. 301-306, 2008, doi: https://doi.org/10.1007/s11670-008-0301-z.

[110] N. Sima et al., "RNA interference against HPV16 E7 oncogene leads to viral E6 and E7 suppression in cervical cancer cells and apoptosis via upregulation of $\mathrm{Rb}$ and $\mathrm{p} 53$," Apoptosis, vol. 13, pp. 273-281, 2008, doi: https://doi.org/10.1007/s10495-007-0163-8.

[111] J. S. Lea et al., "Silencing of HPV 18 Oncoproteins With RNA Interference Causes Growth Inhibition of Cervical Cancer Cells," Reproductive Sciences, vol. 14, no. 1, pp. 20-28, 2007, doi: https://doi.org/10.1177/1933719106298189.

[112] J. Courtête et al., "Suppression of cervical carcinoma cell growth by intracytoplasmic codelivery of anti-oncoprotein E6 antibody and small interfering RNA," Molecular Cancer Therapeutics, vol. 6, no. 6, 2007, doi: https://doi.org/10.1158/1535-7163.MCT-06-0808.

[113] T. Fujii et al., "Intratumor injection of small interfering RNA-targeting human papillomavirus 18 E6 and E7 successfully inhibits the growth of cervical cancer," International Journal of Oncology, vol. 29, no. 3, pp. 541-548, 2006, doi: https://doi.org/10.3892/ijo.29.3.541.

[114] X.-Y. Niu, Z.-L. Peng, W.-Q. Duan, H. Wang, and P. Wang, "Inhibition of HPV 16 E6 oncogene expression by RNA interference in vitro and in vivo," International Journal of Gynecological Cancer: Official Journal of the International Gynecological Cancer Society, vol. 16, no. 2, pp. 743-751, 2006, doi: 10.1111/j.1525-1438.2006.00384.x.

[115] S. Tang, M. Tao, J. P. McCoy Jr., and Z.-M. Zheng, "The E7 Oncoprotein Is Translated from Spliced E6*I Transcripts in High-Risk Human Papillomavirus Type 16- or Type 18Positive Cervical Cancer Cell Lines via Translation Reinitiation," Journal of Virology, vol. 80, no. 9, 2006, doi: https://doi.org/10.1128/JVI.80.9.4249-4263.2006.

[116] R. Koivusalo, E. Krausz, H. Helenius, and S. Hietanen, "Chemotherapy Compounds in Cervical Cancer Cells Primed by Reconstitution of p53 Function after Short Interfering RNAMediated Degradation of Human Papillomavirus 18 E6 mRNA: Opposite Effect of siRNA in Combination with Different Drugs," Molecular Pharmacology, vol. 68, no. 2, pp. 372-382, 2005, doi: https://doi.org/10.1124/mol.105.011189.

[117] M. Jiang, C. P. Rubbi, and J. Milner, "Gel-Based Application of siRNA to Human Epithelial Cancer Cells Induces RNAi-Dependent Apoptosis," Oligonucleotides, vol. 14, no. 4, 2004, doi: https://doi.org/10.1089/oli.2004.14.239. 
[118] M. Yoshinouchi et al., "In Vitro and in Vivo Growth Suppression of Human Papillomavirus 16-Positive Cervical Cancer Cells by E6 siRNA," Molecular Therapy, vol. 8, no. 5, pp. 762-768, 2003, doi: https://doi.org/10.1016/j.ymthe.2003.08.004.

[119] K. Butz, T. Ristriani, A. Hengstermann, C. Denk, M. Scheffner, and F. Hoppe-Seyler, "siRNA targeting of the viral E6 oncogene efficiently kills human papillomavirus-positive cancer cells," Oncogene, vol. 22, pp. 5938-5945, 2003, doi: https://doi.org/10.1038/sj.onc. 1206894.

[120] A. H. S. Hall and K. A. Alexander, "RNA Interference of Human Papillomavirus Type 18 E6 and E7 Induces Senescence in HeLa Cells," Journal of Virology, vol. 77, no. 10, pp. 6066-6069, 2003, doi: https://doi.org/10.1128/JVI.77.10.6066-6069.2003.

[121] X. Li et al., "CRISPR/Cas9 nanoeditor of double knockout large fragments of E6 and E7 oncogenes for reversing drugs resistance in cervical cancer," Journal of Nanobiotechnology, vol. 19, no. 231, 2021, doi: https://doi.org/10.1186/s12951-02100970-w.

[122] E. Ehrke-Schulz, S. Heinemann, L. Schulte, M. Schiwon, and A. Ehrhardt, "Adenoviral Vectors Armed with PAPILLOMAVIRUs Oncogene Specific CRISPR/Cas9 Kill HumanPapillomavirus-Induced Cervical Cancer Cells," Cancers, vol. 12, no. 7, p. 1934, 2020, doi: https://doi.org/10.3390/cancers12071934.

[123] K. Ling et al., "Gene Targeting of HPV18 E6 and E7 Synchronously by Nonviral Transfection of CRISPR/Cas9 System in Cervical Cancer," Human gene therapy, vol. 31, no. 5-6, pp. 297-308, 2020, doi: https://doi.org/10.1089/hum.2019.246.

[124] X. Gao et al., "Hyperbranched poly( $\beta$-amino ester) based polyplex nanopaticles for delivery of CRISPR/Cas9 system and treatment of HPV infection associated cervical cancer," Journal of controlled Release : official journal of the Controlled Release Society, vol. 321, pp. 654-668, 2020, doi: https://doi.org/10.1016/j.jconrel.2020.02.045.

[125] Y.-H. Lao et al., "HPV Oncogene Manipulation Using Nonvirally Delivered CRISPR/Cas9 or Natronobacterium gregoryi Argonaute," Advanced Science, vol. 5, no. 7, 2018, doi: https://doi.org/10.1002/advs.201700540.

[126] T. Yoshiba et al., "CRISPR/Cas9-mediated cervical cancer treatment targeting human papillomavirus E6," Oncology Letters, vol. 17, no. 2, pp. 2197-2206, 2019, doi: https://doi.org/10.3892/ol.2018.9815.

[127] S. Park et al., "MiR-9, miR-21, and miR-155 as potential biomarkers for HPV positive and negative cervical cancer," BMC Cancer, vol. 17, no. 1, 2017, doi: https://doi.org/10.1186/s12885-017-3642-5.

[128] K. Gocze et al., "Unique microRNA expression profiles in cervical cancer," Anticancer Research, vol. 33, no. 6, pp. 2561-2567, 2013, doi: https://ar.iiarjournals.org/content/anticanres/33/6/2561.full.pdf.

[129] F. Navarro and J. Lieberman, "miR-34 and p53: New Insights into a Complex Functional Relationship," PLoS ONE, vol. 10, no. 7, 2015, doi: https://doi.org/10.1371/journal.pone.0132767.

[130] S. Zhao, D. Yao, J. chen, N. Ding, and F. Ren, "MiR-20a Promotes Cervical Cancer Proliferation and Metastasis In Vitro and In Vivo," PloS ONE, vol. 10, no. 3, 2015, doi: https://doi.org/10.1371/journal.pone.0120905.

[131] G. Shishodia et al., "Alterations in microRNAs miR-21 and let-7a correlate with aberrant STAT3 signaling and downstream effects during cervical carcinogenesis," Molecular Cancer, vol. 14, 2015, doi: https://doi.org/10.1186/s12943-015-0385-2. 
[132] A. S. Gardiner et al., "MicroRNA analysis in human papillomavirus (HPV)-associated cervical neoplasia and cancer," Infectious Agents and Cancer, Meeting Abstracts vol. 5, 1, p. 26 of 43, 2010, doi: https://doi.org/10.1186/1750-9378-5-S1-A55.

[133] Q. Hu, J. Song, B. Ding, Y. Cui, J. Liang, and S. Han, "miR-146a promotes cervical cancer cell viability via targeting IRAK1 and TRAF6," Oncology Reports, vol. 39, no. 6, pp. 30153024, 2018, doi: https://doi.org/10.3892/or.2018.6391.

[134] Y. Wan et al., "Salivary miRNA panel to detect HPV-positive and HPV-negative head and neck cancer patients," Oncotarget, vol. 8, no. 59, 2017, doi: https://doi.org/10.18632/oncotarget.21725.

[135] X.-J. Luo et al., "Distinguishable Prognostic miRNA Signatures of Head and Neck Squamous Cell Cancer With or Without HPV Infection," Frontiers in Oncology, vol. 10, 2021, doi: https://doi.org/10.3389/fonc.2020.614487.

[136] K. Božinović et al., "Genome-wide miRNA profiling reinforces the importance of miR-9 in human papillomavirus associated oral and oropharyngeal head and neck cancer," Scientific Reports, vol. 9, no. 1, p. 2306, 2019, doi: https://doi.org/10.1038/s41598-01938797-Z.

[137] X. Wang et al., "microRNAs are biomarkers of oncogenic human papillomavirus infections," Procedings of the National Academy of Sciences of the United States of America, vol. 111, no. 11, pp. 4262-4267, 2014, doi: https://doi.org/10.1073/pnas.1401430111.

[138] Z. Fan et al., "MiR-125a suppresses tumor growth, invasion and metastasis in cervical cancer by targeting STAT3," Oncotarget, vol. 6, no. 28, 2015, doi: https://doi.org/10.18632/oncotarget.4457.

Tables

Table 1

siRNA - mediated targeting of HPV E6 and E7 oncogenes

\begin{tabular}{|c|c|c|c|c|}
\hline Target & Delivery vehicle & $\begin{array}{c}\text { Experimental } \\
\text { model }\end{array}$ & Findings & Reference \\
\hline HPV16 E6 & $\begin{array}{l}\text { (DSPC), (DMG-PEG), } \\
\text { and (DSPE-PEG-Ome) } \\
\text { lipid nanoparticle with } \\
\text { targeted antihuman EGFR } \\
\text { mAbs and siRNA - } \\
\text { (tLNP-siRNA) }\end{array}$ & $\begin{array}{l}\text { Cell lines }(\mathrm{FaDu}, \\
\text { 2A3, SCC104, and } \\
\text { SCC90) } \\
\text { Xenograft model } \\
\text { athymic Foxn1 nude } \\
\text { female mice } \\
\text { (SCC104) }\end{array}$ & $\begin{array}{l}>49 \% \text { tumour growth } \\
\text { inhibition with siRNA } \\
\text { E6 in tLNP-siE6 }\end{array}$ & [87] \\
\hline HPV18 E7 & $\begin{array}{c}\text { siRNA+paclitaxel (PTX) } \\
\text { in poly lactic-co-glycolic } \\
\text { acid (PLGA) } \\
\text { nanoparticles surrounded } \\
\text { by camouflaging HeLa } \\
\text { cell membranes } \\
\text { (Si/PNPs@HeLa) }\end{array}$ & $\begin{array}{l}\text { Cell line (HeLa) } \\
\text { Xenograft model } \\
\text { BALB/c nude mice } \\
\text { (HeLa) }\end{array}$ & $\begin{array}{l}>80 \% \text { tumour growth } \\
\text { inhibition with siRNA } \\
\text { E7 in Si/PNPs@HeLa }\end{array}$ & [88] \\
\hline HPV16 E6 & $\begin{array}{l}\text { Oligofectamine } \\
\text { (Invitrogen) }\end{array}$ & Cell line (CaSki) & $\begin{array}{l}>42 \% \text { loss of cell } \\
\text { viability due to apoptosis } \\
\text { with siRNA }\end{array}$ & [89] \\
\hline
\end{tabular}




\begin{tabular}{|c|c|c|c|c|}
\hline HPV16 E6/E7 & $\begin{array}{l}\text { Oligofectamine } \\
\text { (Invitrogen) }\end{array}$ & $\begin{array}{l}\text { Cell lines (SCC2, } \\
\text { SCC104, SCC90 } \\
\text { and 147T) } \\
\text { Xenograft model } \\
\text { BALB/c nude mice } \\
\quad \text { (SCC104) }\end{array}$ & $\begin{array}{c}\text { 16E6/E7 siRNA resulted } \\
\text { in }>35 \% \text { growth tumour } \\
\text { inhibition }\end{array}$ & {$[90]$} \\
\hline $\begin{array}{c}\text { HPV18 E6/E7 } \\
\text { HPV16 E6/E7 } \\
\text { MCL-1 } \\
\text { (antiapoptotic } \\
\text { protein) }\end{array}$ & $\begin{array}{l}\text { Oligofectamine } \\
\text { (Invitrogen) }\end{array}$ & $\begin{array}{c}\text { Cell lines (CaSki, } \\
\text { SiHa, UPSCI- } \\
\text { SCC154, C4II, } \\
\text { HaCaT) }\end{array}$ & $\begin{array}{l}\text { siRNA MCL1 plus } \\
\text { siRNA E7 resulted in } \\
\text { apoptosis of CaSki } \\
(10 \%), \text { SiHa }(26 \%), \\
\text { UPSCI-SCC154 }(9 \%) \text {, } \\
\text { C4II }(6 \%)\end{array}$ & [91] \\
\hline $\begin{array}{l}\text { HPV18 E6/E7 } \\
\text { HPV16 E6/E7 }\end{array}$ & $\begin{array}{c}\text { DharmaFECT transfection } \\
\text { reagent (Thermo } \\
\text { Scientific,USA) }\end{array}$ & $\begin{array}{c}\text { Cell lines (HeLa } \\
\text { CaSki) } \\
\\
\text { Xenograft model } \\
\text { BALB/c nude mice } \\
\text { (HeLa) }\end{array}$ & $\begin{array}{l}\text { Simultaneous use of } \\
\text { 18E6/E7 siRNA with } \\
\text { cisplatin, and paclitaxel } \\
\text { resulted in }>60 \% \text { growth } \\
\text { tumour inhibition }\end{array}$ & [92] \\
\hline $\begin{array}{l}\text { HPV18 E6/E7 } \\
\text { HPV16 E6/E7 }\end{array}$ & $\begin{array}{l}\text { Core-shell type polyion } \\
\text { complex micelles with } \\
\text { biocompatible outer shell } \\
\text { of modified polyethylene } \\
\text { glycol (PIC micelles) } \\
\text { Lipofectamine } 2000 \\
\text { (Invitrogen) }\end{array}$ & $\begin{array}{c}\text { Cell lines (HeLa } \\
\text { CaSki, SiHa, C33A) } \\
\\
\text { Xenograft model } \\
\text { BALB/c nude mice } \\
\text { (HeLa and SiHa) }\end{array}$ & $\begin{array}{c}\text { SiHa and HeLa cell } \\
\text { tumours were reduced } \\
\text { by } 60 \% \text { post-treatment } \\
\text { with PIC micelles loaded } \\
\text { with si16E6/E7 and } \\
\text { si18E6/E7 }\end{array}$ & [93] \\
\hline HPV18 E7 & $\begin{array}{l}\text { PEGylated liposomes } \\
\text { encapsulating siRNA } \\
\text { (PLEsiRNA) }\end{array}$ & Cell line (HeLa) & $\begin{array}{l}\text { PLEsiRNA with siRNA } \\
\text { 18E7 diminished mRNA } \\
\text { expression in HeLa cells }\end{array}$ & [94] \\
\hline HPV16 E7 & $\begin{array}{l}\text { Lipofectamine } 2000 \\
\text { (Invitrogen) }\end{array}$ & Cell line (CaSki) & $\begin{array}{l}\text { 16E7 siRNA diminished } \\
\text { HPV16 E7 protein } \\
\text { expression }\end{array}$ & [95] \\
\hline HPV16 E6/E7 & $\begin{array}{c}\text { RNAiFect Transfection } \\
\text { Reagent (Qiagen, USA) } \\
\text { for cells } \\
\text { 1,2-dioleoyl-sn-glycero-3- } \\
\text { phosphatidylcholine } \\
\text { (DOPC) neutral } \\
\text { nanoliposomes (NP) for } \\
\text { mice }\end{array}$ & $\begin{array}{c}\text { Cell line TC-1 } \\
\text { (murine C57BL/6 } \\
\text { lung epithelial cells } \\
\text { transformed with } \\
\text { HPV16 E6, E7 and } \\
\text { h-ras oncogenes) } \\
\text { Xenograft model } \\
\text { C57BL/6 }\end{array}$ & $\begin{array}{l}65 \% \text { tumour reduction } \\
\text { after treatment with } \\
\text { siRNAE7-DOPC-NP }\end{array}$ & [96] \\
\hline $\begin{array}{l}\text { HPV18 E6/E7 } \\
\text { HPV16 E6/E7 }\end{array}$ & $\begin{array}{c}\text { DharmaFect } \\
\text { (Dharmacon, Lafayette, } \\
\text { CO, USA) }\end{array}$ & $\begin{array}{l}\text { Cell lines (HeLa, } \\
\text { Hela-Luc, SiHa) } \\
\\
\text { Xenograft model } \\
\text { BALB/c nude mice } \\
(\mathrm{HeLa})\end{array}$ & $\begin{array}{l}>50 \% \text { growth tumour } \\
\text { inhibition with radiation } \\
\text { and HPV18 or HPV16 } \\
\text { E6/E7-specific siRNAs }\end{array}$ & [97] \\
\hline HPV16 E6/E7 & $\begin{array}{l}\text { Cationic liposome- } \\
\text { encapsulated siRNAs } \\
\text { (ClesiRNA) }\end{array}$ & $\begin{array}{l}\text { Cell line (TC-1) } \\
\text { Xenograft model } \\
\text { C57BL/6 (TC-1_ }\end{array}$ & $\begin{array}{l}60 \% \text { tumour inhibition } \\
\text { post-administration of } \\
\text { liposome encapsulated } \\
\text { with bicistronic E6/E7 } \\
\text { siRNA }\end{array}$ & [98] \\
\hline
\end{tabular}




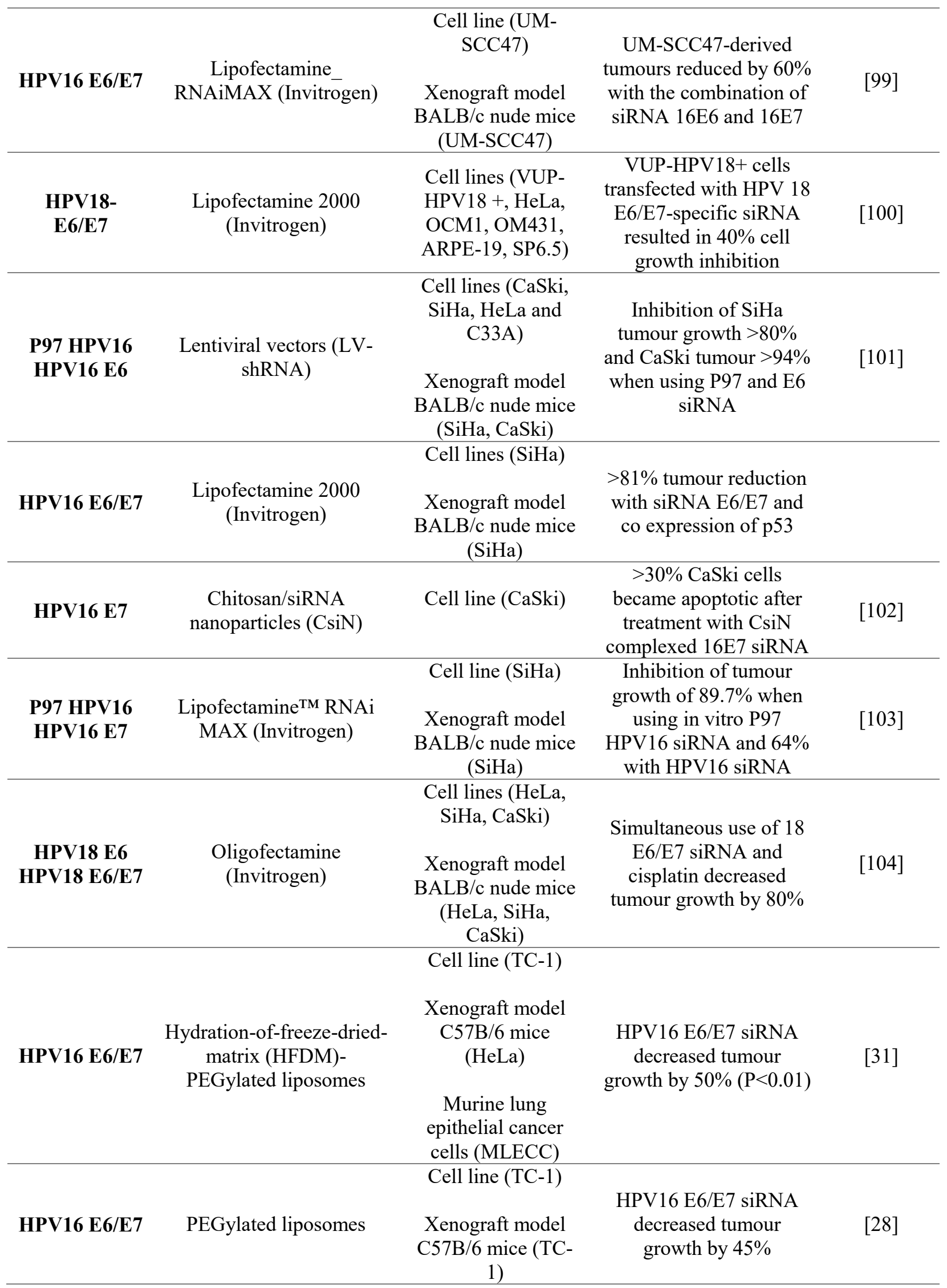




\section{MLECC}

\begin{tabular}{|c|c|c|c|c|}
\hline $\begin{array}{l}\text { HPV18 E6/E7 } \\
\text { HPV16 E6/E7 }\end{array}$ & $\begin{array}{l}\text { Lipofectamine } 2000 \\
\text { (Invitrogen) in cells }\end{array}$ & $\begin{array}{l}\text { Cell lines (HeLa, } \\
\text { CaSki, C33A) } \\
\text { Xenograft model } \\
\text { BALB/c AnN- } \\
\text { Foxn1nu/CrlNarl } \\
\text { nude mice (HeLa) }\end{array}$ & $\begin{array}{c}\text { HPV-18E6 siRNA } \\
\text { decreased tumour } \\
\text { growth }>50 \% \text { at day } 30\end{array}$ & [105] \\
\hline $\begin{array}{c}\text { P97 } \\
\text { (Promoter of } \\
\text { HPV16 } \\
\text { E6/E7) } \\
\end{array}$ & $\begin{array}{c}\text { CodeBreaker siRNA } \\
\text { Transfection Reagent } \\
\text { (Promega) }\end{array}$ & $\begin{array}{l}\text { Cell lines (SiHa, } \\
\text { C33A) }\end{array}$ & $\begin{array}{l}\text { siRNA P97 induced } 4.4 \\
\pm 0.8 \% \text { apoptosis and } \\
57.1 \pm 4.4 \% \text { cell death }\end{array}$ & [106] \\
\hline HPV16 E6/E7 & $\begin{array}{c}\text { Dharmacon RNA } \\
\text { Technologies' SiQuest } \\
\text { transfection reagent }\end{array}$ & $\begin{array}{l}\text { Cell line (CaSki) } \\
\text { Xenograft model } \\
\text { female nu/nu } \\
\text { athymic mice } \\
\text { (CaSki) }\end{array}$ & $\begin{array}{c}>75 \% \text { tumour reduction } \\
\text { with siRNA E6 and a } \\
60 \% \text { tumour reduction } \\
\text { with siRNA E7 }\end{array}$ & [107] \\
\hline HPV16 E6/E7 & $\begin{array}{l}\text { Lipofectamine } 2000 \\
\text { (Invitrogen) }\end{array}$ & $\begin{array}{l}\text { Cell lines (CaSki, } \\
\text { SiHa, HeLa, SK- } \\
\text { OV-3) } \\
\text { Xenograft model } \\
\text { NOD/SCID mice } \\
\text { (SiHa) }\end{array}$ & $\begin{array}{l}>35 \% \text { reduction in } \\
\text { tumour volume with } \\
\text { siRNA targeting E6/E7 }\end{array}$ & [108] \\
\hline HPV16 E6/E7 & $\begin{array}{l}\text { Lipofectamine } 2000 \\
\text { (Invitrogen) }\end{array}$ & Cell line (SiHa) & $\begin{array}{l}\text { siRNA E6 }+ \text { E7 induced } \\
63.7 \% \text { of cell apoptosis }\end{array}$ & [109] \\
\hline HPV16 E7 & $\begin{array}{l}\text { Lipofectamine } 2000 \\
\text { (Invitrogen) }\end{array}$ & $\begin{array}{l}\text { Cell lines (SiHa, } \\
\text { CaSki, C33A) }\end{array}$ & $\begin{array}{c}\text { pSIREN-16E7 } \\
\text { transfected } \\
\text { SiHa cells underwent } \\
\text { apoptosis }(>50 \%)\end{array}$ & [110] \\
\hline $\begin{array}{l}\text { HPV18 E6 } \\
\text { HPV18 E7 }\end{array}$ & $\begin{array}{l}\text { Oligofectamine } \\
\text { (Invitrogen) }\end{array}$ & $\begin{array}{l}\text { Cell lines (HeLa, } \\
\text { C4I, H1299) }\end{array}$ & $\begin{array}{l}\text { Majority of E6 and7- } \\
\text { siRNA treated HeLa } \\
\text { cells died }\end{array}$ & [111] \\
\hline $\begin{array}{l}\text { HPV16 E6 } \\
\text { HPV18 E6 }\end{array}$ & $\begin{array}{l}\text { HiPerFect } \\
\text { (Qiagen) }\end{array}$ & $\begin{array}{l}\text { Cell lines (HeLa, } \\
\text { CaSki, SiHa) }\end{array}$ & $\begin{array}{c}80 \% \text { reduction in cell } \\
\text { proliferation when } \\
\text { treated with a } \\
\text { combination of siRNA16 } \\
\text { E6, 4C6 (antibody } \\
\text { against HPV16 E6), and } \\
\text { K15C (allows formation } \\
\text { of antibody-lipid } \\
\text { complex) }\end{array}$ & [112] \\
\hline HPV18 E6/E7 & $\begin{array}{l}\text { sureFECTOR (B-Bridge } \\
\text { International) }\end{array}$ & $\begin{array}{l}\text { Cell lines (HeLa, } \\
\text { SKG-II, SKG-IIIa) } \\
\text { Xenograft model } \\
\text { athymic nude mice } \\
\text { (SKG-II) }\end{array}$ & $\begin{array}{c}>65 \% \text { of tumour growth } \\
\text { reduction when treated } \\
\text { with HPV18 E6/E7 } \\
\text { siRNAs and } \\
\text { atelocollagen }\end{array}$ & [113] \\
\hline HPV16 E6 & $\begin{array}{l}\text { TransMessenger }{ }^{\mathrm{TM}} \text {, } \\
\text { Qiagen, Valencia, CA }\end{array}$ & Cell line (CaSki) & $\begin{array}{l}\text { CaSki cells derived } \\
\text { tumours reduced by }\end{array}$ & [114] \\
\hline
\end{tabular}




\begin{tabular}{|c|c|c|c|c|}
\hline & & $\begin{array}{l}\text { Xenograft model } \\
\text { mice (CaSki) }\end{array}$ & $\begin{array}{c}>75 \% \text { after treatment } \\
\text { with HPV16 E6 siRNA }\end{array}$ & \\
\hline $\begin{array}{l}\text { HPV16 E6/E7 } \\
\text { HPV18 E6/E7 }\end{array}$ & $\begin{array}{l}\text { Oligofectamine } \\
\text { (Invitrogen) }\end{array}$ & $\begin{array}{l}\text { Cell lines (CaSki, } \\
\text { SiHa, HeLa) }\end{array}$ & $\begin{array}{l}\text { siRNAs targeting E6 } \\
\text { reduced HeLa cell } \\
\text { viability by } 60 \% \text { to } 80 \%\end{array}$ & [115] \\
\hline HPV18 E6 & $\begin{array}{c}\text { Lentiviral vectors (LV- } \\
\text { shRNA) } \\
\text { 18-E61/18E6-2 }\end{array}$ & $\begin{array}{l}\text { Cell line (HeLa) } \\
\text { Xenograft model } \\
\text { Rag-/- mice (HeLa) }\end{array}$ & $\begin{array}{l}\text { High dose }(4 \mathrm{x}) \text { of } \mathrm{LV}- \\
\text { shRNA } 18 \mathrm{E} 6-1 \text { caused } \\
\text { complete tumour } \\
\text { ablation }\end{array}$ & [32] \\
\hline HPV18 E6/E7 & $\begin{array}{l}\text { Oligofectamine } \\
\text { (Invitrogen) }\end{array}$ & Cell line (HeLa) & $\begin{array}{c}\text { 18E6 siRNA decreased } \\
\text { the number of surviving } \\
\text { HeLa CMV cell clones } \\
\text { by } \sim 20 \%\end{array}$ & [116] \\
\hline $\begin{array}{l}\text { HPV16 E6 } \\
\text { HPV18 E6 }\end{array}$ & $\begin{array}{l}\text { Oligofectamine } \\
\text { (Invitrogen) } \\
\text { RNAi lentivirus }\end{array}$ & $\begin{array}{l}\text { Cell lines (SiHa, } \\
\text { CaSki, HeLa, } \\
\text { C33A) }\end{array}$ & $\begin{array}{c}\text { CaSki cells after } \\
\text { transfection with siRNA } \\
\text { E6 reduced cell viability } \\
\qquad 60 \% \\
\text { HeLa cells infected with } \\
\text { lentivirus delivering a } \\
\text { shRNA plasmid against } \\
\text { HPV18 E6 in HeLa with } \\
\text { cisplatin reduced cell } \\
\text { viability }>60 \%\end{array}$ & [33] \\
\hline HPV16 E7 & $\begin{array}{l}\text { Agarose/liposome/E7 } \\
\text { siRNA formulation (gel) }\end{array}$ & Cell line (SiHa) & $\begin{array}{c}>19 \% \text { of SiHa cells } \\
\text { became apoptotic after } \\
\text { gel delivery containing } \\
\text { E7 siRNA }\end{array}$ & [117] \\
\hline HPV16 E6 & $\begin{array}{l}\text { Lipofectamine } 2000 \\
\text { (Invitrogen) }\end{array}$ & $\begin{array}{l}\text { Cell lines (SiHa, } \\
\text { COS-1) } \\
\text { Xenograft model } \\
\text { NOD/SCID mice }\end{array}$ & $\begin{array}{l}>40 \% \text { reduction in } \mathrm{SiHa} \\
\text { cell-derived tumour } \\
\text { volume post-treatment } \\
\text { with HPV16 E6 } \\
\text { targeting siRNAs }\end{array}$ & [118] \\
\hline $\begin{array}{l}\text { HPV16 E6 } \\
\text { HPV18 E6 }\end{array}$ & $\begin{array}{l}\text { Oligofectamine } \\
\text { (Invitrogen) }\end{array}$ & $\begin{array}{l}\text { Cell lines (HeLa, } \\
\text { SiHa, MCF-7, } \\
\text { MeWo, H1299) }\end{array}$ & $\begin{array}{l}\text { siRNAs targeting } \\
\text { HPV16 E6 or HPV18 E6 } \\
\text { resulted in increased p53 } \\
\text { expression and cell } \\
\text { apoptosis }\end{array}$ & [119] \\
\hline HPV18 E7 & $\begin{array}{l}\text { Oligofectamine } \\
\text { (Invitrogen) }\end{array}$ & $\begin{array}{l}\text { Cell lines (HeLa, } \\
\text { C33A) }\end{array}$ & $\begin{array}{l}\text { E7 siRNA reduced E7 } \\
\text { and E6 protein } \\
\text { expression and induces } \\
\text { senescence }>80 \% \text { in } \\
\text { HeLa cells }\end{array}$ & [120] \\
\hline HPV16 E6/E7 & $\begin{array}{c}\text { Oligofectamine } \\
\text { (Life Technologies) }\end{array}$ & $\begin{array}{l}\text { Cell lines (CaSki, } \\
\text { SiHa) }\end{array}$ & $\begin{array}{c}>20 \% \text { cells became } \\
\text { apoptotic after } \mathrm{E} 7 \\
\text { siRNA treatment in } \mathrm{SiHa}\end{array}$ & [22] \\
\hline
\end{tabular}

Table 2

CRISPR - mediated targeting of HPV E6 and E7 oncogenes 


\begin{tabular}{|c|c|c|c|c|}
\hline Target & $\begin{array}{c}\text { Delivery } \\
\text { vehicle/Transfection } \\
\text { process }\end{array}$ & $\begin{array}{c}\text { In vitro/In vivo } \\
\text { model }^{1}\end{array}$ & Findings & Reference \\
\hline $\begin{array}{c}\text { HPV18 } \\
\text { E6/E7 }\end{array}$ & $\begin{array}{l}\text { 1,2-dioleoyl-3- } \\
\text { trimethylammonium- } \\
\text { propane (chloride salt) } \\
\text { (DOTAP) liposomes }\end{array}$ & $\begin{array}{c}\text { Cell lines (HeLa, } \\
\text { HEK293, RD, } \\
\text { A549, HEPG2, 4T1, } \\
\text { CaSki) } \\
\text { Xenograft model } \\
\text { Female BALB/c } \\
\text { nude mice (HeLa) }\end{array}$ & $\begin{array}{c}>95 \% \text { HeLa cells tumour } \\
\text { growth inhibition with } \\
\text { 18E6/E6 sgRNA } \\
\text { CRISPR/Cas9 plus } \\
\text { docetaxel inside liposome } \\
\text { DOTAP }\end{array}$ & {$[121]$} \\
\hline $\begin{array}{l}\text { HPV16 E6 } \\
\text { HPV18 E6 }\end{array}$ & $\begin{array}{l}\text { High-capacity adenoviral } \\
\text { vectors (HCAdVs) }\end{array}$ & $\begin{array}{l}\text { Cell lines (HeLa, } \\
\text { SiHa, CaSk, A549) }\end{array}$ & $\begin{array}{l}>85 \% \text { SiHa significant } \\
\text { cell reduction with } \\
\text { HPV16-E6-specific } \\
\text { CRISPR-HCAdV, the } \\
\text { other cells were not } \\
\text { significant }\end{array}$ & [122] \\
\hline $\begin{array}{l}\text { HPV18 } \\
\text { E6/E7 }\end{array}$ & $\begin{array}{l}\text { Lipofectamine } 3000 \\
\text { (Invitrogen) }\end{array}$ & $\begin{array}{c}\text { Cell lines (SiHa, } \\
\text { HeLa) } \\
\text { Xenograft model } \\
\text { BALB/c nude mice } \\
\text { (HeLa) }\end{array}$ & $\begin{array}{c}>59 \% \text { SiHa cells tumour } \\
\text { growth inhibition with } \\
\text { 18E6/E6 sgRNA } \\
\text { CRISPR/Cas9 }\end{array}$ & {$[123]$} \\
\hline $\begin{array}{c}\text { HPV16 } \\
\text { E6/E7 } \\
\text { HPV18 } \\
\text { E6/E7 }\end{array}$ & $\begin{array}{l}\text { X-tremeGene HP with } \\
\text { nucleofection } \\
\text { (Roche) }\end{array}$ & $\begin{array}{c}\text { Cell lines (SiHa, } \\
\text { HeLa, C33-A) } \\
\text { Xenograft model } \\
\text { Female BALB/c } \\
\text { nude mice (SiHa, } \\
\text { HeLa) }\end{array}$ & $\begin{array}{c}>70 \% \text { SiHa cells tumour } \\
\text { growth inhibition with } \\
\text { 16E6 crRNA } \\
\text { CRISPR/Cas13a }\end{array}$ & {$[50]$} \\
\hline $\begin{array}{l}\text { HPV16 E7 } \\
\text { HPV18 E7 }\end{array}$ & $\begin{array}{c}\text { Poly(amide-amine)- } \\
\text { poly( }(\beta \text {-amino ester) } \\
\text { hyperbranched copolymer } \\
\text { (hPPC)/PBAE-GFP } \\
\text { polyplex nanoparticles }\end{array}$ & $\begin{array}{c}\text { Cell lines (SiHa, } \\
\text { HeLa) } \\
\text { Xenograft model } \\
\text { Female nude (nu/nu) } \\
\text { mice (SiHa) }\end{array}$ & $\begin{array}{c}90 \% \text { tumour growth } \\
\text { inhibition (SiHa cells) } \\
\text { with hPPC1-16E7 } \\
\text { CRISPR/Cas9 }\end{array}$ & {$[124]$} \\
\hline $\begin{array}{l}\text { HPV16 E7 } \\
\text { HPV18 E7 }\end{array}$ & PEGylated liposomes & $\begin{array}{l}\text { Cell lines (HeLa, } \\
\text { CasKi) } \\
\text { Xenograft model } \\
\text { Rag } 1 \text { mice (HeLa, } \\
\text { CasKi) }\end{array}$ & $\begin{array}{c}100 \% \text { HeLa cells tumour } \\
\text { clearance with } 18 \mathrm{E} 7 \text { and } \\
\text { CasKi cells tumour with } \\
\text { 16E7 gRNA } \\
\text { CRISPR/Cas9 }\end{array}$ & {$[40]$} \\
\hline HPV18 E7 & $\begin{array}{c}\text { Self-assembled micelle } \\
\text { composed of quaternary } \\
\text { ammonium-terminated } \\
\text { poly (propylene oxide) } \\
\text { (PPO-NMe }) \text { and } \\
\text { amphiphilic Pluronic F127 } \\
\text { (F127/ PPO-NMe3/pCas9- } \\
\text { GFP) }\end{array}$ & $\begin{array}{l}\text { Cell line (HeLa) } \\
\text { Xenograft model } \\
\text { Female nude (nu/nu) } \\
\text { mice }(\mathrm{HeLa})\end{array}$ & $\begin{array}{l}>38 \% \text { tumour growth } \\
\text { inhibition with (F127/ } \\
\text { PPO-NMe3/pCas9- } \\
\text { GFP/gRNA) micelles } \\
\text { with E7 gRNA }\end{array}$ & {$[125]$} \\
\hline
\end{tabular}




\begin{tabular}{|c|c|c|c|c|}
\hline HPV18 E6 & $\begin{array}{l}\text { Adeno-associated virus } \\
\text { (AAV) vector }\end{array}$ & $\begin{array}{c}\text { Cell lines (HeLa, } \\
\text { HCS-2, SKG-1, } \\
\text { HEK293) } \\
\\
\text { Xenograft model } \\
\text { BALB/c nude mice } \\
\text { (SKG-1) }\end{array}$ & $\begin{array}{c}>85 \% \text { tumour growth } \\
\text { inhibition with E6 gRNA } \\
\text { CRISPR/Cas } 9\end{array}$ & [126] \\
\hline $\begin{array}{c}\text { HPV16 } \\
\text { E6/E7 } \\
\text { Promoter } \\
\text { of HPV16 } \\
\text { E6/E7 } \\
\end{array}$ & $\begin{array}{l}\text { Lipofectamine } 2000 \\
\text { (Invitrogen) }\end{array}$ & $\begin{array}{c}\text { Cell lines (SiHa, } \\
\text { C33-A) } \\
\text { Xenograft model } \\
\text { BALB/c nude mice } \\
\text { (SiHa) }\end{array}$ & $\begin{array}{c}>90 \% \text { tumour growth } \\
\text { inhibition with } \\
\text { promoter+E6+E7 gRNA } \\
\text { CRISPR/Cas9 }\end{array}$ & [39] \\
\hline HPV16 E7 & $\begin{array}{c}\text { X-tremeGENE HP DNA } \\
\text { transfection reagent } \\
\text { (Roche) } \\
\text { jetPEI polymer-based } \\
\text { DNA transfection reagent } \\
\text { (Polyplus) }\end{array}$ & $\begin{array}{l}\text { Cell lines (SiHa, } \\
\text { CaSki, HEK293, } \\
\text { C33A) }\end{array}$ & $\begin{array}{c}56 \% \text { apoptosis in } \mathrm{SiHa} \\
\text { cells and } 48 \% \text { apoptosis } \\
\text { in CaSki cells with E7 } \\
\text { gRNA CRISPR/Cas9 }\end{array}$ & [38] \\
\hline $\begin{array}{c}\text { HPV18 } \\
\text { E6/E7 } \\
\text { HPV16 } \\
\text { E6/E7 } \\
\end{array}$ & $\begin{array}{l}\text { FuGENE® } 6 \\
\text { (Promega) }\end{array}$ & $\begin{array}{l}\text { Cell lines (HeLa, } \\
\text { CaSki) }\end{array}$ & $\begin{array}{c}>80 \% \text { with E6 sgRNA } \\
\text { and }>56 \% \text { with E7 } \\
\text { sgRNA apoptosis in HeLa } \\
\text { cells }\end{array}$ & [37] \\
\hline
\end{tabular}

Table 3 miRNAs in HPV derived cancers

\begin{tabular}{|c|c|c|c|}
\hline \multirow{2}{*}{$\begin{array}{l}\text { Expression } \\
\text { status }\end{array}$} & \multicolumn{2}{|c|}{ miRNAs } & \multirow{2}{*}{ References } \\
\hline & Cervical cancers & Head and neck cancers & \\
\hline Upregulated & $\begin{array}{c}\text { miR-9, miR-10b*, miR-15a*, } \\
\text { miR-16 (4), miR-20a (2), mir- } \\
\text { 20b*, miR-21 (5), miR-25, } \\
\text { miR-27a, miR-34a (4), miR- } \\
\text { 92a, miR-106b, miR-124, } \\
\text { miR-135b, miR-141, miR- } \\
\text { 146a, miR-155, miR-182 (2), } \\
\text { miR-183, miR-196a, miR- } \\
\text { 210, miR-221, miR-223, miR- } \\
\text { 301b, miR-378, miR-449a }\end{array}$ & $\begin{array}{l}\text { miR-9 }(3), \text { miR-10b*, } \\
\text { miR-15a*, miR-16, miR- } \\
\text { 20b*, miR-134, miR-210, } \\
\text { miR-455, miR-196b, miR- } \\
\text { 338, miR-376c, miR-378a, } \\
\text { miR-380, miR-493 }\end{array}$ & $\begin{array}{l}\text { CC [61, } \\
63-66,127- \\
133] \\
\text { HNC [61, } \\
67,134- \\
136]\end{array}$ \\
\hline Downregulated & $\begin{array}{c}\text { miR-22, miR-27a, miR-29a, } \\
\text { and miR-100, miR-125a, } \\
\text { miR-126, miR-195, miR-218, } \\
\text { let-7a, miR-139-3p*, miR- } \\
145^{*}, \text { miR-381* and miR- } \\
\text { 574-3p* }\end{array}$ & $\begin{array}{c}\text { miR-29, miR-139-3p* } \\
\text { miR-145*, miR-381* and } \\
\text { miR-574-3p* }\end{array}$ & $\begin{array}{l}\mathrm{CC}[61,63, \\
131,132, \\
137,138] \\
\mathrm{HNC}[61, \\
136]\end{array}$ \\
\hline
\end{tabular}

*both upregulated/downregulated in $\mathrm{CC}$ and $\mathrm{HNC}$ 


\section{Figures}

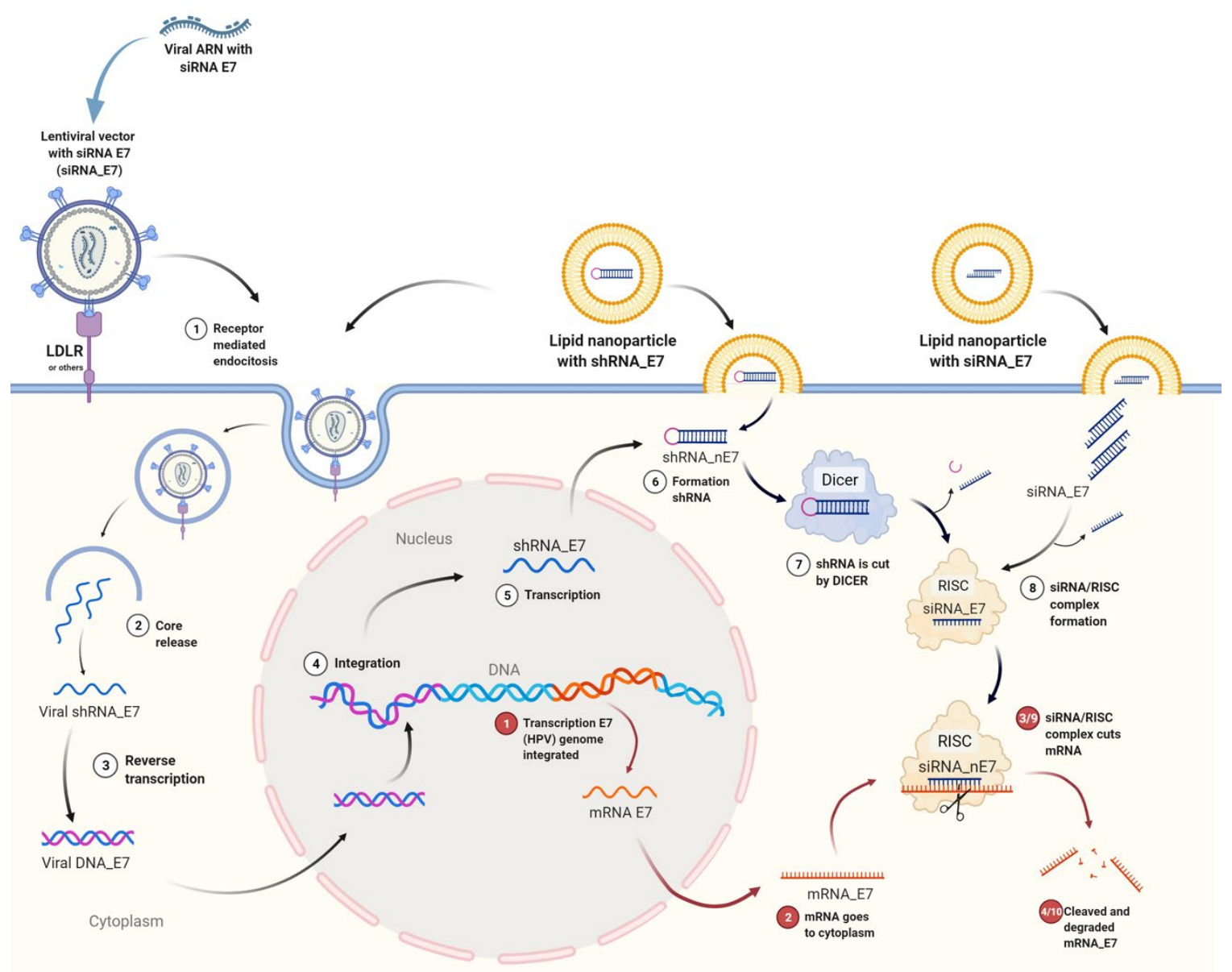

Figure 1 Mechanism of action of therapeutic RNAi targeting HPV E7 delivered using

lentiviruses or lipid nanoparticles. RNAi targeting HPV E7 mRNA can either be delivered using lipid nanoparticles of lentiviral vectors. Lentiviral vectors carrying short hairpin RNA (shRNA) is taken up by cells through receptor-mediated endocytosis. Viral material containing targeting shRNA is then released into the cytosol, reverse transcribed before intergrating into the host cell genome. The shRNA is then expressed and released into the cytosol. On the other hand, naked shRNA and siRNAs can also be delivered into the cells using lipid nanoparticles (LNPs), which will release the RNAi cargo into the cytosol. shRNA is cut by an RNAse III endonuclease, DICER, 
and forms a protein complex called RNA induced silencing complex (RISC), whereas exogenous siRNA directly forms a complex with RISC. Here the siRNA-RISC complex cuts the complementary E7 mRNA resulting in endonucleolytic mRNA cleavage and subsequent loss of E7 expression. Figure was created with BioRender.com. 